Research article

\title{
A comprehensive approach to understanding flood risk drivers at the municipal level
}

\author{
Pedro Pinto Santos ${ }^{a, *}$, Susana Pereira ${ }^{a}$, Jose Luís Zêzere ${ }^{a}$, Alexandre Oliveira Tavares ${ }^{\mathrm{b}}$, \\ Eusebio Reis ${ }^{a}$, Ricardo A.C. Garcia ${ }^{a}$, Sergio Cruz Oliveira ${ }^{a}$ \\ ${ }^{a}$ Centre for Geographical Studies of the Institute of Geography and Spatial Planning, Universidade de Lisboa (CEG-IGOT-ULisboa), Edifício IGOT, Rua Branca Edmee \\ Marques, Cidade Universitaria, 1600-276, Lisboa, Portugal \\ ${ }^{\mathrm{b}}$ Centre for Social Studies, Earth Sciences Department of the Sciences and Technology Faculty, Universidade de Coimbra (CES/DCT-FCT-UCoimbra), Colegio S. \\ Jeronimo, Largo D. Dinis, 3000-995, Coimbra, Portugal
}

\section{A R T I C L E I N F O}

\section{Keywords:}

Flood risk

Hazard

Exposure

Vulnerability

Portuguese municipalities

\begin{abstract}
A B S T R A C T
During the period 1998-2017, floods were responsible for $11 \%$ of the loss of life and $23 \%$ of the economic loss caused by climate-related and geophysical-related disasters worldwide. An integrated and effective definition of flood risk management strategies therefore still requires synthesized and comprehensive knowledge about the driving forces of flood risk.

In this study, 278 Portuguese municipalities are analyzed and classified according to flood hazard, exposure, and vulnerability. After evaluating the three components that describe risk, an index of the flood risk is calculated and a cluster analysis is further performed to understand the role of the risk drivers (hazard, exposure, and vulnerability) in each municipality. The proposed approach therefore provides flood risk indexes on a municipal basis, which are built upon different sources of both cell-by-cell data and an aggregation of municipal-level data that has been statistically validated. Municipalities both in the NW part of the country and along the valleys of major rivers demonstrate a significant superimposition of high levels of exposure and hazard, while vulnerability presents a disperse pattern throughout the country.

The results obtained using this approach should contribute to the diversification of flood risk management strategies. This is still lacking in the majority of the national-level flood risk governance processes, namely those strategies that focus on the contingency of daily activities and those aiming at a long-term reduction of the exposure, vulnerability, and hazard components that shape flood disasters.
\end{abstract}

\section{Introduction}

In the context of climate change, the increase in the frequency of storms that is occurring because of rising temperatures accompanied by an increase in evaporation in a framework of rising temperatures will lead to a higher frequency, severity, and non-seasonality of intense and often prolonged rainfall events that cause floods. However, regional predictions related to precipitation are marked with significant uncertainty and geographical variability (IPCC and IPCC5 WGII, 2014). In Europe, the average stream flow is expected to decrease in the Iberian basins, whereas extreme runoff indicators such as the 100-year daily peak flow will probably increase in the Iberian northern and central basins (Douro and Tagus), while a reduction is likely in the southern basins (Alfieri et al., 2015). These drivers of the future climate may have distinct effects, according to the type of flood (e.g. slow onset or flash floods), leading to complexity in the prediction of future changes in terms of the types of floods and their yearly distribution (Turkington et al., 2016).

Damage to the built environment due to river flooding alone accounts for US $\$ 104$ billion in average annual losses (UNISDR, 2015a). In a recent report focusing on climate-related and geophysical disasters, floods are reported as responsible for a total of US $\$ 656$ billion in economic losses over the period 1998-2017 (23\% of the total), which was only surpassed by earthquakes and storms (Wallemacq et al., 2017). Floods also caused 142,088 fatalities (11\% of the total) between 1998 and 2017 according to the same report. Considering the criteria of the

\footnotetext{
* Corresponding author.

E-mail addresses: pmpsantos@campus.ul.pt (P.P. Santos), susana-pereira@campus.ul.pt (S. Pereira), zezere@campus.ul.pt (J.L. Zêzere), atavares@ci.uc.pt (A.O. Tavares), eusebioreis@campus.ul.pt (E. Reis), rgarcia@campus.ul.pt (R.A.C. Garcia), cruzdeoliveira@campus.ul.pt (S.C. Oliveira).
} 
EM-DAT for the inclusion of disastrous events, it is expected that the contribution of small disasters to these figures might be underestimated. Such possible underestimation regarding floods would be greater than that of other, more ubiquitous, hazardous processes such as earthquakes, tsunami, or tropical storms. Despite these economic losses, disaster databases show a reducing trend in the number of flood-related fatalities during the past few decades in both Europe (Paprotny et al., 2018b) and Portugal (Pereira et al., 2016). In the HANZE pan-European database which spans the period from 1870 to 2016, the Portuguese NUTS3 are classified as very susceptible to floods, compared to the rest of Europe (TU-Delft, n.d.).

Risk management strategies, when interpreted by the light of the Sendai framework for disaster risk reduction (DRR), should be aimed at reducing risk and losses. This can be achieved by both prevention of new disasters and reducing the existing disaster risk through the "implementation of integrated and inclusive economic, structural, legal, social, health, cultural, educational, environmental, technological, political and institutional measures that prevent and reduce hazard, exposure and vulnerability" (UNISDR, 2015b: 12). This requires a comprehensive and holistic collation of disaster-related knowledge at a local level (Tavares and Santos, 2013), including the risk of flooding (Green et al., 2013; Hegger et al., 2018; Koks et al., 2015; Merz et al., 2010; Santos and Tavares, 2015; Schanze, 2012; Sudhaus et al., 2008). European countries have recently begun to face the challenge of preparing flood risk management plans that prioritize prevention, preparedness, and protection via the conjugation of five types of flood risk management (FRM) strategies: risk prevention, defense, mitigation, preparation, and recovery (Dieperink et al., 2016). FRM needs to be supported by the most accurate, adequate, and comprehensive knowledge about the driving forces that define, mitigate, and accommodate flood risk (e.g. Hartmann and Driessen, 2017; Hobeica and Santos, 2016; Schumann, 2011). The scientific approaches that are adopted to acquire such knowledge need to take into consideration the sectors and scale when FRM-related decisions are to be made (Driessen et al., 2016; Geaves and Penning-Rowsell, 2016; Ward et al., 2015, 2013).

In Portugal, as well as in other European countries, the majority of the funding directed to FRM is allocated to flood defense (Hegger et al., 2018). The same authors identify the lack of resources, the need for continuing and maintaining previously adopted measures (designated "sunk costs" and "path-dependency"), and the demonstrated fact that recent flood events frequently reinforce the already dominant logic of flood defense as a barrier to the diversification of FRM strategies. Public participation in the risk governance process faces several constraints: a lack of experience and awareness of flood risk, misperceptions of risk and a lack of financial resources to support the implementation of property-level mitigation measures (Fournier et al., 2016). Finally, the complexity in evaluating the effectiveness of structural - but mainly the non-structural - measures used for flood risk mitigation renders the development of evidence-based policy-making regarding FRM strategies and practices difficult (Sayers et al., 2013; Schanze, 2012; Schanze et al., 2008).

Scientific literature is rich in presenting specific and transversal indices that can be used to describe either risk or some of the components of risk. The global INFORM multi-risk index is a theoretically robust risk index, combining data from 16 components that are related to hazard, exposure, vulnerability, and lack of coping capacity (De Groeve et al., 2014). Hazard and exposure are combined into a single dimension, computed at equal weighting with vulnerability and the lack of coping capacity. The INFORM index was designed to be applied at the national level, although there are examples at the municipality level in Colombia or at the cadastral level in Lebanon, where flooding is considered specifically in terms of hazard and exposure. The World Risk Index (WRI) considers an hazard sphere represented by exposure, and a vulnerability-societal sphere that is represented by the likelihood of suffering harm (susceptibility), the lack of coping capacity and the lack of adaptive capacity (Welle and Birkmann, 2015). The two spheres are equally weighted in the WRI score.

Some global indices specifically related to flooding focus solely on the hazard (Dottori et al., 2016; Sampson et al., 2015), or indicate the amount of damage expected via natural and socio-economic factors (Okazawa et al., 2011). Fekete (2009) defined social vulnerability index for flooding at the county level, based on three Principal Component Analysis (PCA) factors that represent the occupancy, population fragility, and socio-economic conditions. Scussolini et al. (2016) collated a global database of flood protection standards for design and policy at distinct administrative levels.

In Portugal, few studies have been carried out in which flood risk components are expressed according to a given administrative unit. Sa and Vicêncio (2011) presented a methodology at the municipal level that combines five sub-indices: historical losses, urban and peri-urban land use, length of the drainage network, hourly maximum rainfall, and population density to produce an output describing the vulnerability to flood risk. The use of hydro-geomorphological risk profiles was also carried out at a municipal level by Santos et al. (2014), considering the role of urban and population growth on the severity of disasters. This research demonstrated the importance of using extensive loss databases concerned with flooding and landslides in order to understand how natural and societal processes can be validated as drivers for disasters. Fernandez et al. (2016) applied a GIS and multi-criteria approach in which the social vulnerability to flooding was evaluated within a Portuguese municipality, analyzing 3076 neighborhoods. Ferrari et al. (2019) has also recently assessed the territorial resilience and flood vulnerability at an infra-municipal level based on a set of 59 variables, most of which come from the population census, but including other sources related to the environment, social equipment, and public infrastructure.

In this study, Portuguese municipalities are characterized and classified in terms of their hazard to fluvial flooding, exposure, and vulnerability. The research is focused on fluvial floods caused by excessive precipitation in urban, rural, and natural areas. Because of the climate and dimensions of the basins, both flash floods and progressive (or slow-onset) deluges occur in the area investigated. Any type of marine/coastal floods caused by storm-surges or flooding caused by subsidence and rise of aquifer levels were excluded from this analysis. Finally, a flood risk index (FRI) is proposed combining the three main risk components and a cluster analysis of the FRI results for the municipalities is performed in order to identify the main driving forces for the risk from flooding in the study area. A discussion is also provided concerning the construction of the index and its limitations, as well as the applicability of the index to risk management.

\section{Study area}

Portugal is located on the southwest quadrant of the Iberian peninsula, covering a total area of $89000 \mathrm{~km}^{2}$ with an elevation that ranges from $0 \mathrm{~m}$ at sea level to $1993 \mathrm{~m}$ in the central mountains (Fig. 1). Approximately $9 \%$ of the territory is at an elevation below $50 \mathrm{~m}$ and approximately $53 \%$ of the country is below $250 \mathrm{~m}$. These areas include most of the human occupancy (c. $80 \%$ of the $10.047 \quad 10^{6}$ inhabitants of mainland Portugal, according to the 2011 population census). In the last decades, the Portuguese territory has recorded a remarkable concentration of the population along the coastal and low-lying areas, in contrast to the rural areas inland (Salgueiro et al., 2005).

Portugal has a Mediterranean climate, and is designated Csb in the northern zone (roughly north of the Mondego river) and Csa in the remaining study area. Mediterranean climates are characterized by the coincidence of hot and dry conditions in the summer and a strong variability in the amount of annual rainfall (Ferreira et al., 2005; Ventura, 1987). The mean annual precipitation in Portugal is $882 \mathrm{~mm}$ (1971-2000), ranging from more than $3000 \mathrm{~mm}$ in the northwestern mountains to less than $600 \mathrm{~mm}$ in the Douro valley east of Peso da Regua and in the inner area of Alentejo (roughly covering the area between 


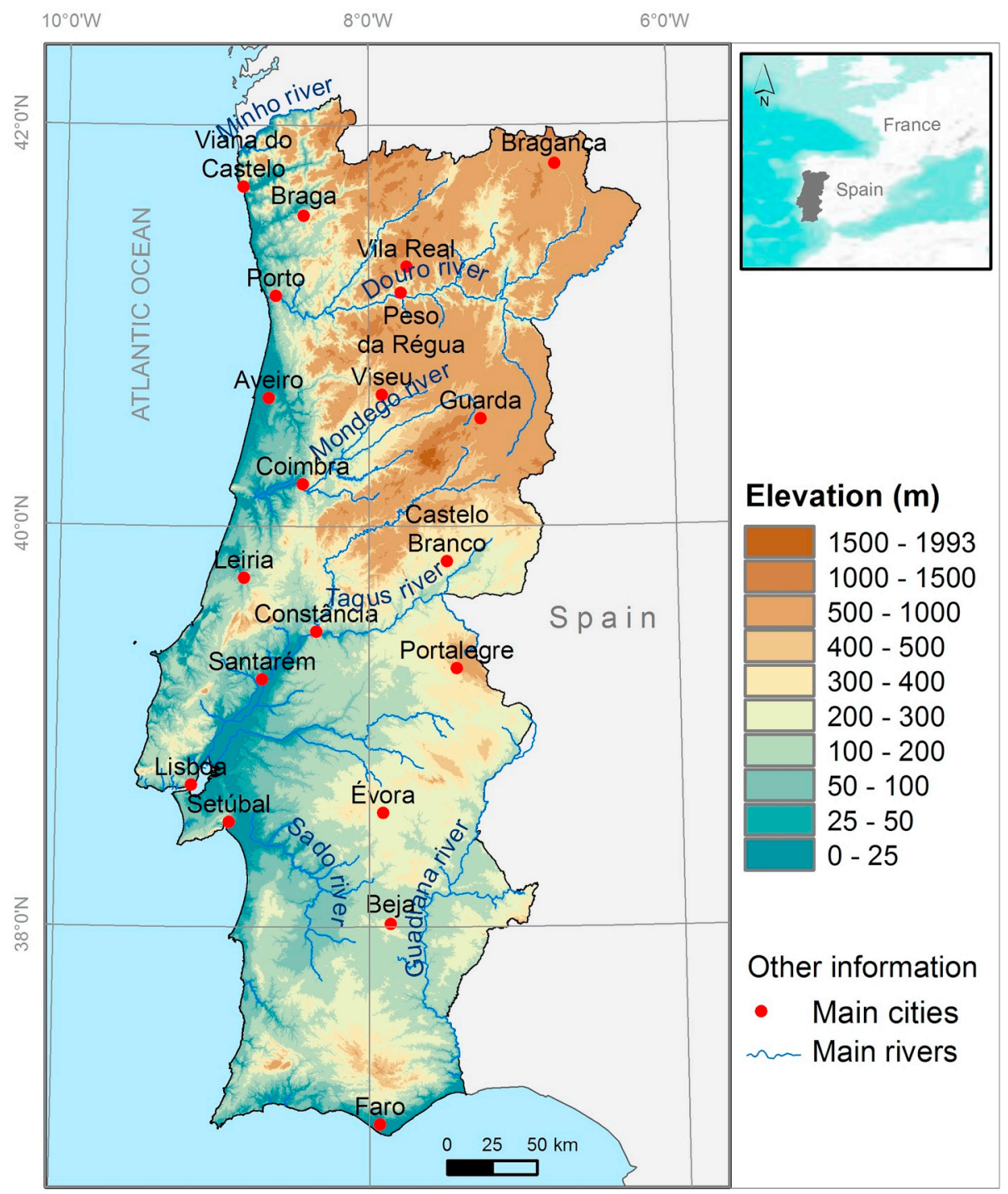

Fig. 1. Geographic context of Portugal.

Portalegre and Beja in Fig. 1). Rainfall events that result in floods are more frequently associated with southwestern, western, and cyclonic weather types (Pereira et al., 2018; Ramos et al., 2014; Ramos and Reis, 2002). Portugal is mainly affected by two types of floods; slow-onset floods which are more frequent between November and February and flash floods which occur predominantly in the Autumn and Winter (Ramos and Reis, 2001), but can occur at any time of the year (Zêzere et al., 2014). Slow-onset floods are particularly predominant around the major rivers that drain the transboundary basins: the Douro, Tagus, and Guadiana (Fig. 1). Flash floods can be particularly frequent, and serious, when they occur in urban areas (Oliveira and Ramos, 2002) or newly urbanized areas (Trigo et al., 2016). The main cities identified in Fig. 1 represent district capitals, except for Peso da Regua and Constância, which were included because of the severity of the impact caused by floods in these cities (caused by the Douro and Tagus rivers, respectively) reported in historical databases such as the DISASTER database (Zêzere et al., 2014). This database was recently updated to cover the period 1865-2015, reporting 1018 casualties, 130 missing, 479 injured, 14088 evacuated, and the displacement of 40687 people because of floods. The number of 1018 fatalities (cf. Fig. 2-B) is strongly marked by the mortality verified in a single event; a flash flood that occurred near Lisbon on November 25-26 1967, which was responsible for approximately 700 casualties, although only 522 were reported by newspapers at the time (Pereira et al., 2017). The role of exposure in controlling flood disasters is evident in the cities of Porto and Lisbon, and their respective metropolitan areas, as well as in Coimbra (Fig. 2-A).

\section{Data and methods}

An overview of the input data used to define the hazard, exposure and vulnerability components forming the municipal flood risk index (FRI) is presented in Table 1.

As described below, some of the variables presented in Table 1 are disclosed in sub-indices that are calculated from other intermediate input data. When variables were expressed as a function of the municipality area (percentages and densities), the marshlands and other intertidal areas - identified through the land use data from the Portuguese Territory General Directorate (DGT, 2015) - were removed from the accountable municipal area. This avoids a biased representation of municipalities that include significant areas of land in the two mentioned land use classes (in particular, those on the riverside of the Tagus, Vouga, and the Sado estuaries, and the Faro coastal lagoon).

Each variable was scaled to the range $[0,1]$ following the min-max method (Eq. (1)) prior to integration into the FRI:

$x_{i, \text { norm }}^{m} \frac{x_{i}^{m} \quad x_{i, \min }}{x_{i, \max } \quad x_{i, \min }}$ 

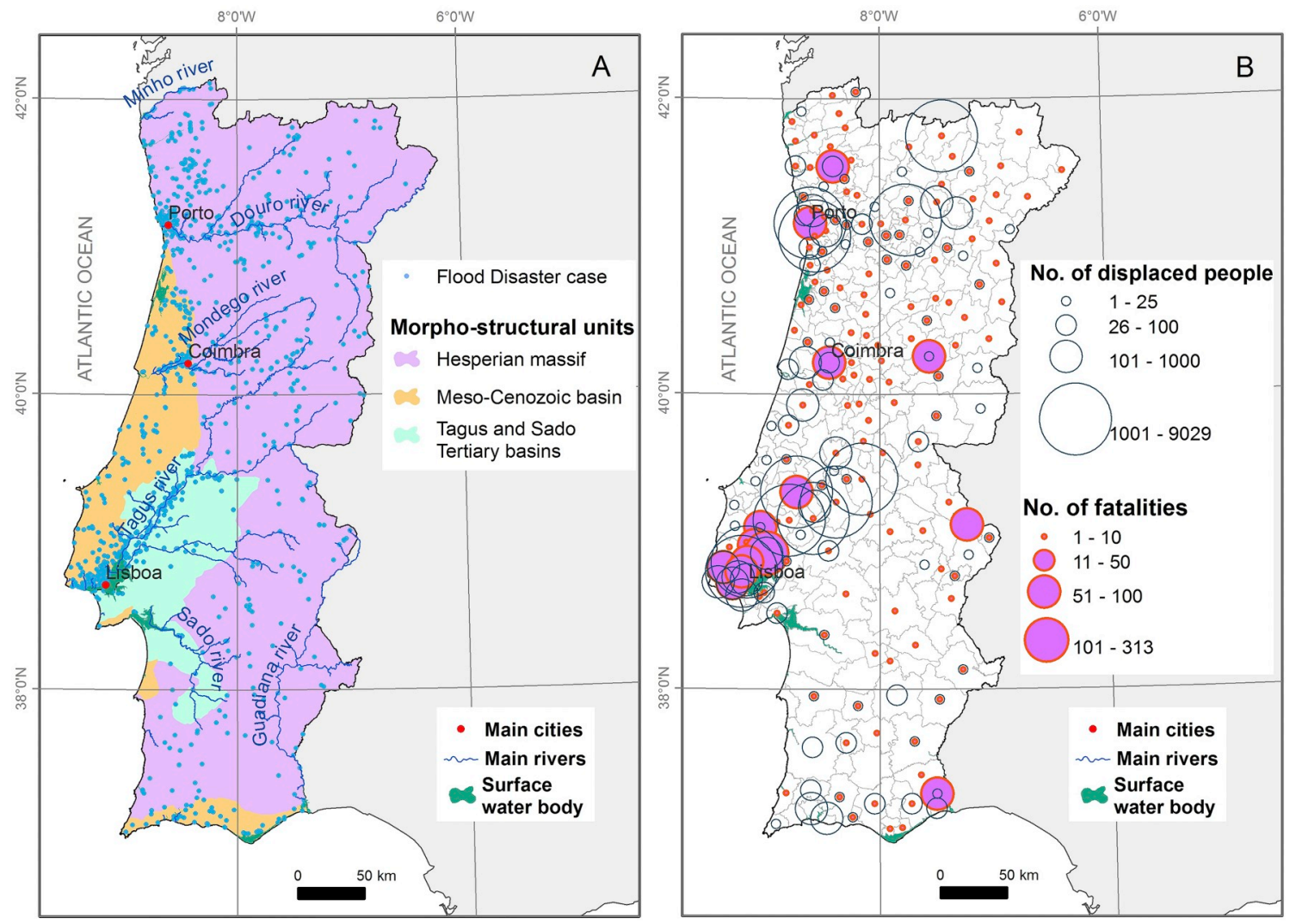

Fig. 2. Flood disaster cases in Portugal (A), and the number of fatalities and displaced people caused by floods per municipality (B) in the period (1865-2015).

Table 1

Input data used to assess flood risk components, adjusted to the municipal level.

\begin{tabular}{|c|c|c|c|}
\hline $\begin{array}{l}\text { Flood risk } \\
\text { component }\end{array}$ & $\begin{array}{l}\text { Variables adjusted to the } \\
\text { municipality level }\end{array}$ & Units & Abbrev. \\
\hline \multirow[t]{2}{*}{ Hazard } & $\begin{array}{l}\text { Flood susceptibility (average of } \\
\text { stream flood susceptibility and } \\
\text { flooded areas) }\end{array}$ & Dimensionless & SUSCF \\
\hline & Weather and climate events index & Dimensionless & WCE \\
\hline \multirow[t]{3}{*}{ Exposure } & Population density & $\begin{array}{l}\text { Inhabitants/ } \\
\mathrm{km}^{2}\end{array}$ & PD \\
\hline & $\begin{array}{l}\text { Average road density per } \\
\text { municipality }\end{array}$ & $\mathrm{km} / \mathrm{km}^{2}$ & $\mathrm{RD}$ \\
\hline & Average degree of imperviousness & $\%$ & ADI \\
\hline Vulnerability & Social vulnerability in 2017 & Dimensionless & SV \\
\hline
\end{tabular}

where: $x_{i}^{m}$ is the data of the $m$-th municipality from the $i$-th dataset of the indicator; $x_{i, \min }$ is the minimum value for the $i$-th dataset of the indicator; $x_{i, \max }$ is the maximum value in the $i$-th dataset of the indicator; and $x_{i, \text { norm }}^{m}$ is the normalized data or the $m$-th municipality from the $i$-th dataset of the indicator.

\subsection{Flood hazard}

The term 'flood hazard' refers to the probability of the occurrence of a flood with a given severity in a defined area and with a defined interval of recurrence. In this research, this conceptualization was operationalized by considering (i) the spatial propensity of an area to flooding or flood susceptibility (SUSCF) and (ii) the weather and climate events index (WCE) as an indicator of the frequency of rainfall events, from which flood peak flows may be generated. The national scale of this research requires the adoption of a methodological and conceptual approach that can be applied uniformly over an extensive area, and which results are comparable at the municipal level.

\subsubsection{Flood susceptibility}

The physical constraints of floods were assessed based on a nationalscale flood susceptibility assessment that uses two inputs: stream flood susceptibility (SFS) and main flood-prone areas (MFPA).

Stream flood susceptibility (SFS) assessment is based on the methodology presented by Reis (2011) that has recently been applied to Portugal (Santos et al., 2019), from which the SFS at the municipal level is calculated. The method considers three flood-conditioning factors flow accumulation, slope angle and relative permeability - and takes into account the cumulative effect of these factors along the entire contributing area, which includes in some cases their transboundary area. The SFS is expressed as a matrix with a resolution of approximately $80 \mathrm{~m}$, ranging from 5 to 10 (dimensionless values). Several combinations of the conditioning factors were tested against the databases describing flood loss, as described in Santos et al. (2019). The model selected was that which best correlated the SFS scores with the spatial distribution of occurrences ( 0.85 for flow accumulation, 0.10 for slope angle, and 0.05 for relative permeability). An average score was calculated for each municipality in order to define the municipal SFS, which is one of the inputs used for flood susceptibility (Fig. 3-A), resulting in values from 5.0 to 8.9. This approach has the advantage of valuing the characteristics of the entire watershed.

The following method was used to identify the main flood-prone areas (MFPA): 1) extraction of the drainage network identified during the SFS assessment (grid cells with a SFS 5). These polygons were then combined in a GIS environment with adjacent areas where the slope angles were 2 . The 2 threshold is validated as a proxy for floodplains when topologically connected to a stream network. Because some of the resulting polygons still included slopes and hilltops, it was necessary to overlay them with the areas with Height Above Nearest Drainage (HAND) 2 (Nobre et al., 2011). Using tabular queries, polygons with a slope angle 2 that were not overlaid with values of HAND 2 were disregarded. The percentage of a municipal area with flood-prone areas 

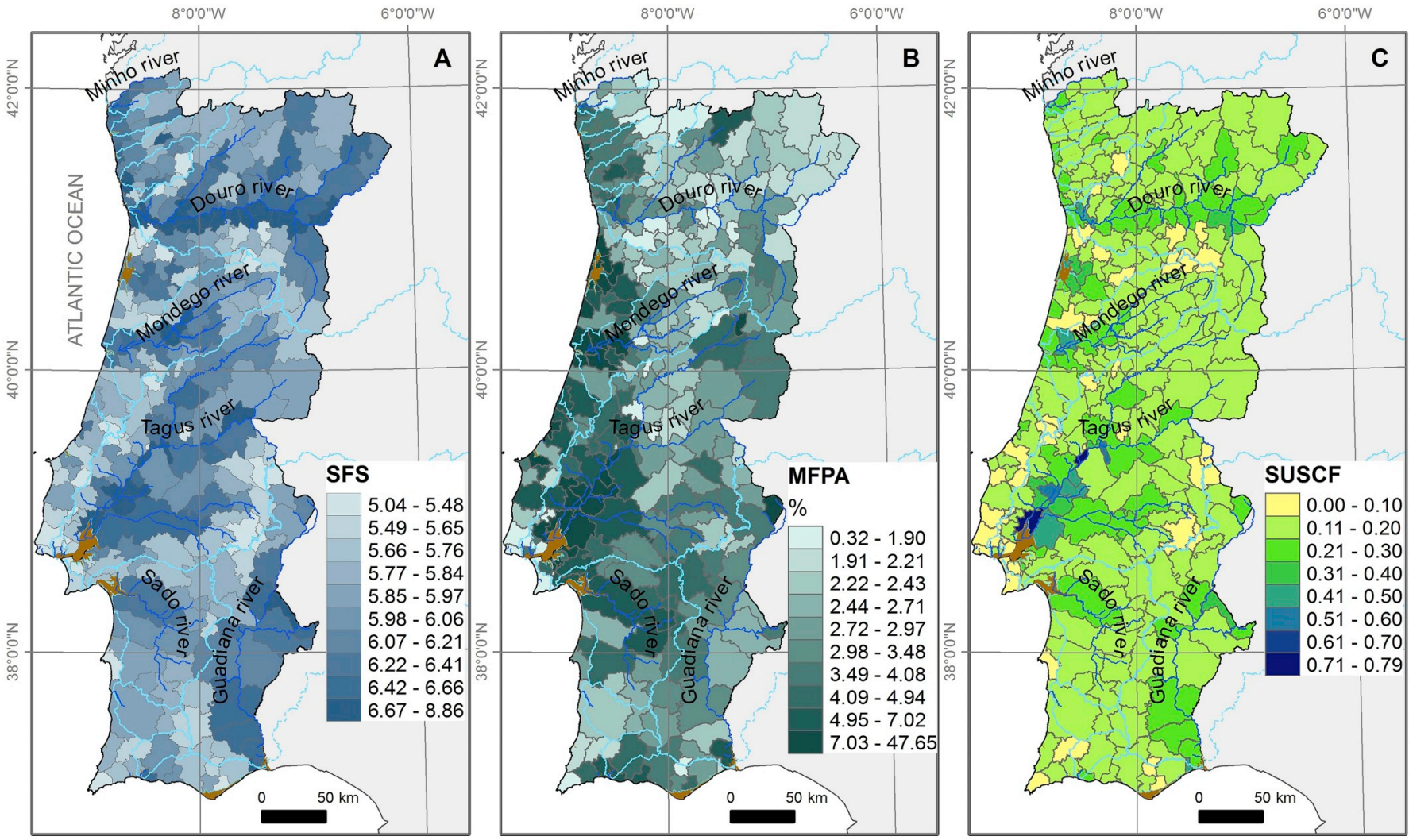

main rivers $\rightarrow$ Basins of major rivers $\rightarrow$ Surface water body

Fig. 3. Stream flood susceptibility, SFS (A); main flood-prone areas, MFPA (B); and flood susceptibility, SUSCF (C) represented per municipality. Values for SFS and MFPA are classified in deciles and the SUSCF is classified using equal intervals.

was then calculated, ranging from 0.3 to $47.7 \%$ (Fig. 3-B).

Flood susceptibility (SUSCF) corresponds to the average of SFS and MFPA (Fig. 3-C). While the SFS provides an insight of the contribution of the entire drainage area of a basin - thus resulting in high scores in municipalities that are crossed by major rivers and in basins with a high average slope and low average permeability -, the MFPA evaluates the local conditions for the accumulation of flood waters. The highest MFPA scores were found to be associated with the morpho-structural units of the Tertiary sedimentary basins of Tagus and Sado, and the western and southern Meso-Cenozoic basins (Fig. 3-B). The vast floodplains of the major rivers are included in these morpho-structural units. Some municipalities located in high plateau zones also feature above average MFPA values.

Flood susceptibility (SUSCF, Fig. 3-C) highlights the municipalities that are crossed by main watercourses (Tagus, Douro, and Guadiana rivers) and regions of high susceptibility that are associated with national river basins, such as the Vouga (Fig. 1, near the city of Aveiro), Mondego, and Sado.

\subsubsection{Weather and climate events}

The variable that is used to express weather and climate events (WCE) is considered another force that drives hydro-geomorphologic hazards and is expressed by two factors: circulation weather types (CWT) and the extreme precipitation susceptibility index (EPSI).

CWTs that have the potential to generate rainfall patterns from which the triggering of flash floods or slow-onset peak flows in Portugal can occur are the cyclonic (C), southwesterly (SW), and westerly (W) circulations (Cortesi et al., 2014; Pereira et al., 2018; Ramos et al., 2014; Trigo and DaCamara, 2000). The frequency of each CWT (C, SW and W) in each municipality was calculated for the period 1946-1990 from the results of Trigo and DaCamara (2000). The cyclonic, southwesterly, and westerly CWTs represent approximately $62 \%$ of the observed daily rainfall in Portugal (Trigo and DaCamara, 2000). The spatial distribution of the normalized coefficients of the regression equation models for C, SW, and W CWTs were used to compute the maximum annual frequency of each CWT by municipality (Fig. 4-A, and C). The values obtained range from 22.5 to $42.5 \%$ for SW, 17.5 and $57.5 \%$ for W, and from 2.5 to $57.5 \%$ for cyclonic weather types.

The EPSI for Portugal was developed by Santos et al. (2017), using rainfall data from the period 1950-2003. The following variables are considered in this index: the maximum 1-day precipitation $(\mathrm{mm})$, the maximum 5-day precipitation ( $\mathrm{mm}$ ), the simple daily intensity index SDII (mm.day ${ }^{1}$ ), the number of days of heavy precipitation ( $20 \mathrm{~mm}$ ), the number of consecutive wet days ( $1 \mathrm{~mm}$ ), and the fraction of the annual total precipitation that exceeds the $95^{\text {th }}$ percentile (\%). All variables were rescaled to the $[0,1]$ interval and summed; higher values represent a high propensity for extreme rainfall conditions (Santos et al., 2017). The annual extreme precipitation susceptibility index generated by municipality was used in this study (Santos et al., 2017). The EPSI ranges from 0.990 to 4.940 over the study area, and is higher in the mountainous regions of north and central Portugal as well as in some of the municipalities located in the south (Fig. 4-D).

Both the CWTs and the EPSI were normalized to the range $[0,1]$ using the min-max method. In order to calculate the WCE index, several combinations of W, SW, C, and EPSI were tested. The reliability parameters of Lambda-2 of Guttman and Cronbach's Alpha were used to identify the combination that best differentiates the spatial distribution of each input. The adopted weighing (Eq. (2)) corresponds to a value of Lambda- 2 of 0.736 and an Alpha of 0.84 .

WCE $\quad 0.3 S W \quad 0.3 W \quad 0.1 C \quad 0.3 E P S I$

Fig. 4-E represents the WCE index per municipality. The 


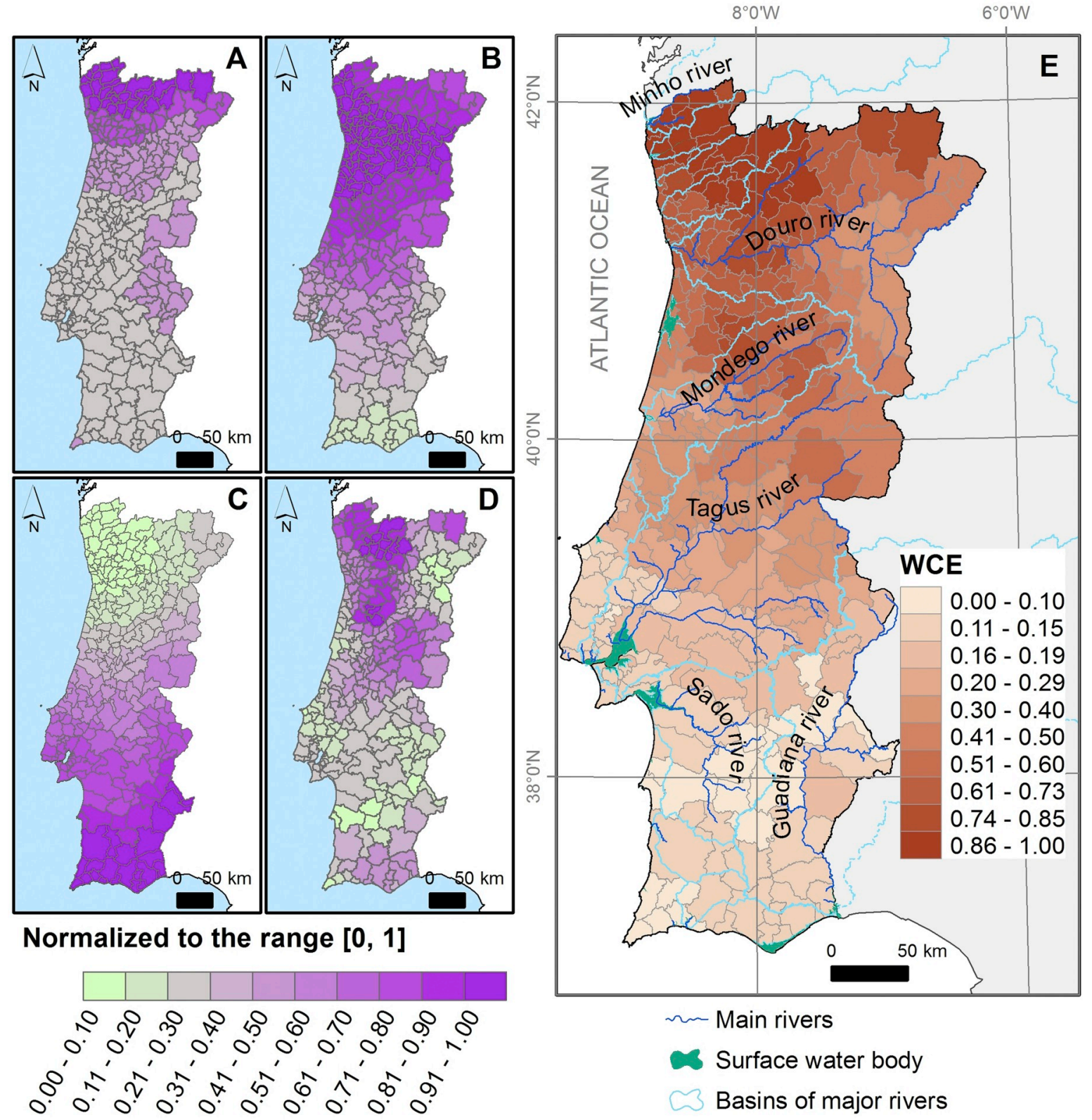

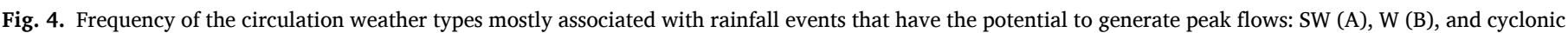

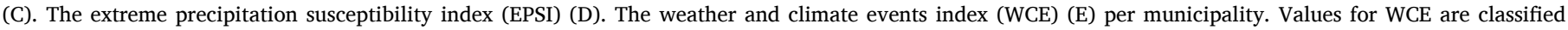
in deciles.

northwestern region is the area where rainfall events occur more frequently having the capacity to generate peak flows. In opposition, the south of the country presents the lower WCE scores.

\subsubsection{Flood hazard index}

The flood hazard index $(\mathrm{H})$ results from the sum of weighted WCE and SUSCF (Eq. (3)):

$$
\text { H SUSCF } w_{i} \quad \text { WCE } w_{j}
$$

In which $w_{i}$ and $w_{j}$ are the weights assigned to SUSCF and WCE in each of the hazard models tested. It was theoretically assumed that SUSCF should be assigned with more weight than WCE, based on the opinion of experts. However, a broader range of models was tested to verify the sensitivity of the hazard index (Table 2).

Validation was carried out by correlating the $\mathrm{H}$ values in the five models with two types of data: a) historical flood marks registered by the Emergency and Civil Protection National Authority, available at APA
(2018); b) the location of 71 areas with high flood risk potential under consideration in the 2nd cycle of the implementation of the Floods Directive. Despite the low Pearson correlation coefficients in all five models - which was to be expected because flood records and impacts do not only account for the natural constraints of flood events considered in the calculation of $\mathrm{H}-$, model $\mathrm{H} 1$ performed better in both correlation analysis regarding the density of flood marks and the location of those areas under a potential risk of flooding by the Floods Directive. Model $\mathrm{H} 1$ was therefore selected as the flood hazard model to be used for the calculation of FRI.

\subsection{Exposure}

Flood exposure is defined as the people, properties, and infrastructure located in areas with the potential to be affected by floods. The assessment of municipal exposure was based on three variables: population density (PD), road density (RD), and the average degree of 
Table 2

Flood hazard models tested using a combination of WCE and SUSCF. Pearson correlation coefficients between the municipal score for each hazard model, the density of flood marks, and the location of the potential areas of flood risk designated by the Floods Directive.

\begin{tabular}{|c|c|c|c|}
\hline \multirow{2}{*}{$\begin{array}{l}\text { Code of } \\
\text { hazard } \\
\text { model }\end{array}$} & \multirow[t]{2}{*}{ Variables weighting } & \multicolumn{2}{|c|}{ Pearson correlation coefficient } \\
\hline & & $\begin{array}{l}\text { Density of } \\
\text { flood marks }\end{array}$ & $\begin{array}{l}\text { Location of Flood } \\
\text { Directive's flood risk } \\
\text { potential areas }\end{array}$ \\
\hline H1 & $\begin{array}{l}\left(\mathrm{SUSCF}^{*} 0.9\right) \\
\left(\mathrm{WCE}^{*} 0.1\right)\end{array}$ & $0.254^{\mathrm{a}}$ & $0.325^{\mathrm{a}}$ \\
\hline $\mathrm{H} 2$ & $\begin{array}{l}(\text { SUSCF*0.75) } \\
(\text { WCE*0.25) }\end{array}$ & $0.171^{\mathrm{a}}$ & $0.225^{\mathrm{a}}$ \\
\hline H3 & $\begin{array}{l}\left(\mathrm{SUSCF}^{*} 0.5\right) \\
\left(\mathrm{WCE}{ }^{*} 0.5\right)\end{array}$ & 0.025 & 0.042 \\
\hline $\mathrm{H} 4$ & $\begin{array}{l}\left(\mathrm{SUSCF}^{*} 0.25\right) \\
(\mathrm{WCE} * 0.75)\end{array}$ & 0.059 & 0.064 \\
\hline H5 & $\begin{array}{l}\left(\mathrm{SUSCF}^{*} 0.1\right) \\
\left(\mathrm{WCE}{ }^{*} 0.9\right)\end{array}$ & 0.089 & 0.101 \\
\hline
\end{tabular}

${ }^{\text {a }}$ Correlation is significant at the 0.01 level (bilateral).

imperviousness (ADI), also mentioned as the degree of soil or surface sealing. In large study areas, such as exposure assessments made on a national-level, similar data was used to provide a common basis so that uniform methodologies could be used and comparable results could be obtained (Paprotny et al., 2018b).

Population density (PD) per municipality (Fig. 5-A), expressed as the number of inhabitants per $\mathrm{km}^{2}$, was calculated from the population census of 2011 (INE, 2011), and ranges from 5.1 to 7363.3 inhabitants $/ \mathrm{km}^{2}$. Road density (RD) per municipality (Fig. 5-B), expressed as the number of $\mathrm{km}$ of road per $\mathrm{km}^{2}$ is calculated from data extracted from the OpenStreetMap $\odot$ Geofabrik mirror, and ranges from 0.6 to 24.4 $\mathrm{km} / \mathrm{km}^{2}$. The average degree of imperviousness (ADI) (Fig. 5-C) was calculated from the "imperviousness degree 2012" layer, available at the portal of the Copernicus' Land Monitoring Service (CLMS, 2012), which represents the percentage of sealed area in 2012. This permeability-related variable plays a role that is distinct from that used in the calculation of SFS (in which the purpose is to estimate soil infiltration). The ADI has the ability to differentiate densely urbanized areas from those with lower levels of occupation, such as suburban, peri-urban, and rural areas. The original $20 \mathrm{~m}$ spatial resolution layer was used to calculate the average value of ADI per municipality, which ranges from 0.3 to $61.6 \%$.

The input data selected to represent exposure highlights coastal municipalities with high populations and road densities as well as high rates of surface sealing. These municipalities correspond to the lowlands and floodplains where high flood hazard is observed.

The distribution of the values for $\mathrm{PD}, \mathrm{RD}$, and $\mathrm{ADI}$ is highly asymmetrical; natural logarithms were therefore applied to the raw values obtained for the municipalities. The values were then scaled to the range $[0,1]$ using the min-max method. Seven combinations of the exposure input data (PD, RD, and $\mathrm{ADI}$ ) were tested in order to perform a sensitivity analysis of the weighting for each variable (Table 3 ).

Exposure is used to represent the elements that can be affected by a hazardous process. The value of exposure is intrinsic and models that measure it cannot be statistically validated against a dependent variable. Table 4 shows that the correlation among the scores of $E$ in all the tested models is both strong and significant. The selection of the exposure model therefore follows more the theoretical arguments than the statistical causal relationships given the evident multicollinearity between the input variables used.

Road density is an indirect indicator of the presence of residential populations at the municipal level, because it takes the presence of streets in built-up areas into consideration, but it can also be used as a proxy for the probability of a transient population who can be affected
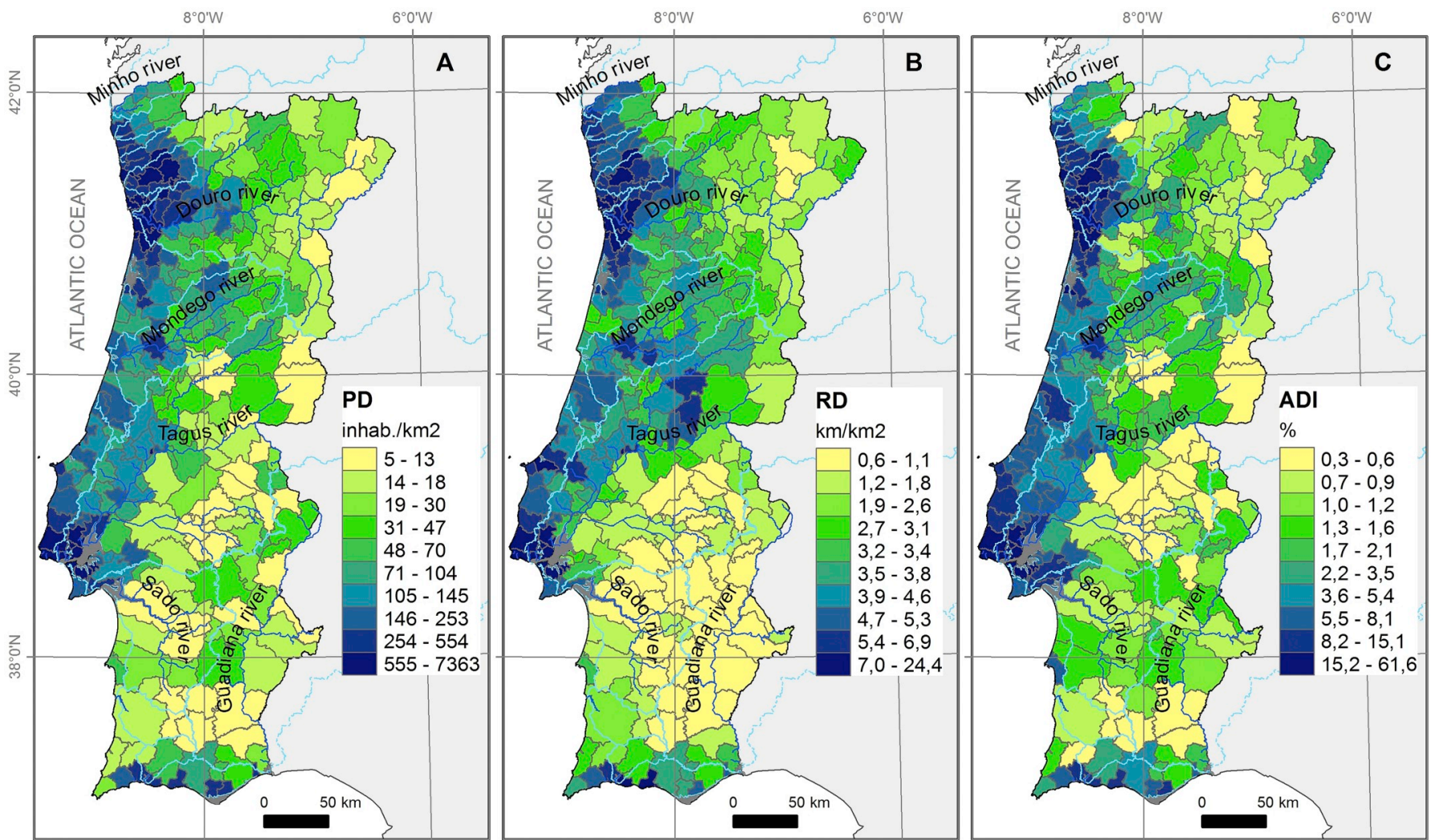

$\sim$ Main rivers $\sim 3$ Basins of major rivers $\backsim$ Surface water body

Fig. 5. Population density (A), road density (B), and average degree of imperviousness (C), per municipality. Classification is in deciles. 
Table 3

Exposure models and the corresponding weight of each variable.

\begin{tabular}{llll}
\hline Code of exposure model & \multicolumn{4}{l}{ Variable weighting } \\
\hline E1 & $\left(\mathrm{PD}^{*} 0.8\right)$ & $\left(\mathrm{RD}^{*} 0.1\right)$ & $\left.(\mathrm{ADI})^{*} 0.1\right)$ \\
E2 & $\left(\mathrm{PD}^{*} 0.1\right)$ & $\left(\mathrm{RD}^{*} 0.1\right)$ & $(\mathrm{ADI} 0.8)$ \\
E3 & $\left(\mathrm{PD}^{*} 0.1\right)$ & $\left(\mathrm{RD}^{*} 0.8\right)$ & $(\mathrm{ADI} 0.1)$ \\
E4 & $\left(\mathrm{PD}^{*} 1 / 3\right)$ & $\left(\mathrm{RD}^{*} 1 / 3\right)$ & $\left(\mathrm{ADI}^{*} 1 / 3\right)$ \\
E5 & $(\mathrm{PD} 0.5)$ & $\left(\mathrm{RD}^{*} 0.25\right)$ & $(\mathrm{ADI} 0.25)$ \\
E6 & $\left(\mathrm{PD}^{*} 0.25\right)$ & $\left(\mathrm{RD}^{*} 0.25\right)$ & $(\mathrm{ADI} 0.5)$ \\
E7 & $\left(\mathrm{PD}^{*} 0.25\right)$ & $\left(\mathrm{RD}^{*} 0.5\right)$ & $(\mathrm{ADI} 0.25)$ \\
\hline
\end{tabular}

either directly or indirectly by hazardous phenomena. This is valid in terms of the impacts that can occur in terms of mobility in a flood disaster, such as the predominance of the cut-offs that occur on affected roads - the most registered impact in flood loss databases -, and the associated economic impacts. Casualties are strongly associated with rural areas, particularly during the crossing of roads, and not with densely populated areas (Pereira et al., 2016). Given the above considerations, model E3 (Table 3) was considered as the best combination for the input data to express the exposure to flooding.

\subsection{Vulnerability}

Vulnerability is the predisposition of exposed elements to be affected by the impacts of a hazard. The social, economic, and infrastructural factors that influence the degree of loss and the ability to recover after a flood event are considered in this study.

The data used to assess the municipal vulnerability derives from a social vulnerability (SV) assessment that follows the methodological steps presented by Mendes et al. (2010) and Mendes et al. (2019). The initial assessment was updated in 2017 using more recent data, mostly from the 2011 population and housing census, using the 278 municipalities as individuals for the statistical procedure of Principal Component Analysis (PCA). Separate PCAs were conducted, one for each of the components of SV: criticality and support capability (Tavares et al., 2018). Criticality expresses individual characteristics that are related to vulnerability and the potential for recovery (such as age, employment, housing conditions, and mobility). The latter expresses the collective equipment and infrastructure (whether public or private) held by a particular territory that contribute to the contingency of activities, the collective and individual recovery and rehabilitation, and the consequential decrease in the impact caused by a disastrous event.

After the elimination of redundant variables, a Kaiser-Meyer-Olkin (KMO) of 0.726 and an explained variance of $73 \%$ were achieved for a criticality-represented set of 22 variables. The set of 12 variables representing support capability feature a KMO of 0.705 and an explained variance of $65 \%$. The respective principal components were interpreted, with any necessary changes made to the cardinality, and the scores in each PC were then summed to provide separate final scores for criticality and support capability. The final SV score is the product of the criticality and support capability, with the later operating in an inverse direction to criticality (Tavares et al., 2018). The SV score at the municipal level ranges from 0 to 0.601 . As mentioned, SV data was scaled to the range $[0,1]$.

\subsection{Flood risk index}

Flood risk is the probability of the occurrence of a flood that can cause direct and indirect impacts on people, property, and the infrastructure. Expressing the risk of flooding at the municipal level as a flood risk index (FRI) implies losing a direct probabilistic relation between the physical processes of flooding in a given exposed element with a given vulnerability. The FRI is therefore a dimensionless and comparable measure of flood risk, calculated at a municipal level and valid for the entire territory of a municipality. FRI is the product of hazard $(\mathrm{H})$, exposure (E), and vulnerability (V), as expressed in Eq. (4):

FRI $\quad H^{1 / 3 *} E^{1 / 3 *} V^{1 / 3}$

This enunciation of FRI, considering the due differences with regards to the scale, risk components, and input data is based on the INFORM risk index (De Groeve et al., 2014). When compared to the simple product of $\mathrm{H}, \mathrm{E}$ and $\mathrm{V}$, used without the exponentiation, the dispersal and increase in the range of the final FRI scores is observed. The median for example, would be 0.0397 if $\mathrm{H}, \mathrm{E}$, and $\mathrm{V}$ were simply multiplied; however, using the product with an exponent of $1 / 3$ produces a median of 0.3410 .

\subsection{Cluster analysis of municipal flood risk}

Clustering was adopted as the statistical multivariate process used to classify the municipalities in homogeneous groups. A hierarchical cluster analysis was conducted in SPSS ${ }^{\circledR}$ using Ward's minimum variance criterion (Ward, 1963). This is an agglomerative hierarchical clustering procedure (bottom up approach) where the criterion for choosing the pair of clusters to merge at each step is based on a minimum increase in the total within-cluster variance after merging. At the initial step, all clusters contain a single object.

Clusters were calculated using the selected models for $\mathrm{H}, \mathrm{E}, \mathrm{V}$, and FRI. The best number of clusters was selected according to the results obtained with Ward's algorithm, the link tree, and the agglomeration cost tables, in order to reduce the number of clusters until a sharp increase occurs in the cost of agglomeration. The number of clusters prior to this increase was then selected. Euclidean distances (not standardized) were used as metric distances and expert opinion was used as the criteria to identify the most adequate number of clusters that best describes the diversity of combinations of $\mathrm{H}, \mathrm{E}, \mathrm{V}$, and FRI.

\section{Results}

\subsection{The components of flood risk}

The model H1 was chosen to represent flood hazard $(\mathrm{H})$. The average $\mathrm{H}$ for each municipality is thus 0.241 , ranging from 0.041 to 0.925 . The spatial distribution of the hazard shows a graded differentiation that

Table 4

Pearson correlation coefficients between the seven exposure models tested. Correlation is always significant at the 0.01 level.

\begin{tabular}{llllllllll}
\hline & DP & RD & ADI & E1 & E2 & E3 & E4 & E5 & E6 \\
\hline DP & 1 & & & & & & & & \\
RD & 0.859 & 1 & & & & & & \\
ADI & 0.950 & 0.822 & 1 & & & & & \\
E1 & 0.998 & 0.883 & 0.96 & 1 & & & & \\
E2 & 0.964 & 0.856 & 0.998 & 0.974 & 1 & & & \\
E3 & 0.911 & 0.993 & 0.881 & 0.931 & 0.910 & 1 & 0.965 & 1 & \\
E4 & 0.979 & 0.926 & 0.969 & 0.989 & 0.983 & 0.999 & 1 \\
E5 & 0.988 & 0.913 & 0.968 & 0.996 & 0.982 & 0.955 & 0.996 & \\
E6 & 0.977 & 0.903 & 0.984 & 0.987 & 0.994 & 0.947 & 0.998 & \\
E7 & 0.963 & 0.957 & 0.946 & 0.977 & 0.966 & 0.985 & 0.996 & 0.991 & 0.988 \\
\hline
\end{tabular}


combines the drainage area upstream of each municipality with the local fluvial morphology that controls the expansion of floodwaters. This combination resulted in the prediction of high hazard for municipalities located in the floodplain of the Tagus river (Fig. 6-A). High and moderate flood hazard is observed in the vestibular areas of medium-sized basins, such as the Douro, Vouga and the Mondego. Low hazard was found for municipalities with a predominance of headwaters and areas of less-developed drainage network.

An average exposure (E) of 0.436 was obtained, ranging from 0.032 to 0.997 (Fig. 6-B). The exposure is lower in the inland municipalities of the Douro river basin and in the southern region of Alentejo, which includes sectors of the Tagus, Guadiana, and Sado river basins. Before applying the natural logarithm, several municipalities with strong and predominantly horizontal urbanization were undervalued in terms of their exposed elements. This was particularly evident considering that the frequency of flood losses with uniquely material consequences (as in buildings and roads) is higher than events with human losses (such as casualties or displacements). The statistical distribution of the average degree of imperviousness was similar to that of population density. The exposure model that values road density as an indicator of comprehensive land use and occupancy, that is prone to be affected by flooding was therefore selected.

Vulnerability by municipality ranges from 0.019 to 1 with an average value of 0.444 , and is higher in the central and northern regions of mainland Portugal (Fig. 6-C). In detail, and particularly relevant to the flood topic, the municipalities near the Douro river present the highest values for vulnerability. The southern region of the Algarve, along with the major cities of Porto and Lisbon and some of their surrounding municipalities, were found to have lower vulnerability. These results are described in detail by Tavares et al. (2018). Concerning criticality, employment and age are relevant drivers of individual vulnerability. The principal components (PC) of criticality express the risk groups (with $30 \%$ of the variance explained), economic conditions (13\%, Tavares et al. (2018)), disadvantaged population (12\%, Tavares et al. (2018)), level of income (7\%, Tavares et al. (2018)), employment (6\%, Tavares et al. (2018)), and a particularly dependent population (5\%, Tavares et al. (2018)). The variables that explain support capability self-grouped around 3 PCs: civil protection response (30\%, Tavares et al. (2018)), economic and environmental dynamism (22\%, Tavares et al. (2018)), and logistics and services capacity (13\%, Tavares et al. (2018)). Deficit in the coverage of the public and private infrastructures and services that ensures the contingency of activities and recovery post-disaster are the major drivers of low support capability.

\subsection{Flood risk index}

The flood risk index (FRI) ranges from 0.050 to 0.630 , with an average value of 0.337 . Although the FRI equation (Eq. (4)) values $\mathrm{H}, \mathrm{V}$, and E equally, FRI is closely correlated to vulnerability (0.656), while a Pearson correlation of 0.590 was observed with hazard and a correlation of 0.434 with exposure. Values for municipal FRI show a normal distribution (Fig. 7). An FRI from 0.3 to 0.4 was observed in 112 (40\%) of the 278 municipalities, while only 13 municipalities have an FRI of above 0.5 (Fig. 7). From the three components of FRI, hazard is the most asymmetric (with a kurtosis ( $\mathrm{k}$ ) equal to 8.55), while for $\mathrm{E} \mathrm{k} \quad 0.13$ and for $\mathrm{Vk} \quad 0.21$. This is explained by the localized and confined expression of flood hazard. In fact, there are historical flood disasters in municipalities where the hazard is confined to narrow areas occupied by villages with moderate or high vulnerability. In Peso da Regua, a municipality near the Douro river $(\mathrm{H} \quad 0.287, \mathrm{E} \quad 0.419, \mathrm{~V} \quad 0.571$, FRI

0.409 ) there was a single event of a progressive flood, February 1979 , which caused more than 2500 displaced persons. There is also the case of Odivelas, near Lisbon, ( $\mathrm{H} \quad 0.113$, E 0.920 , V 0.315 , FRI 0.320), where a single flash flood that occurred in November 1967
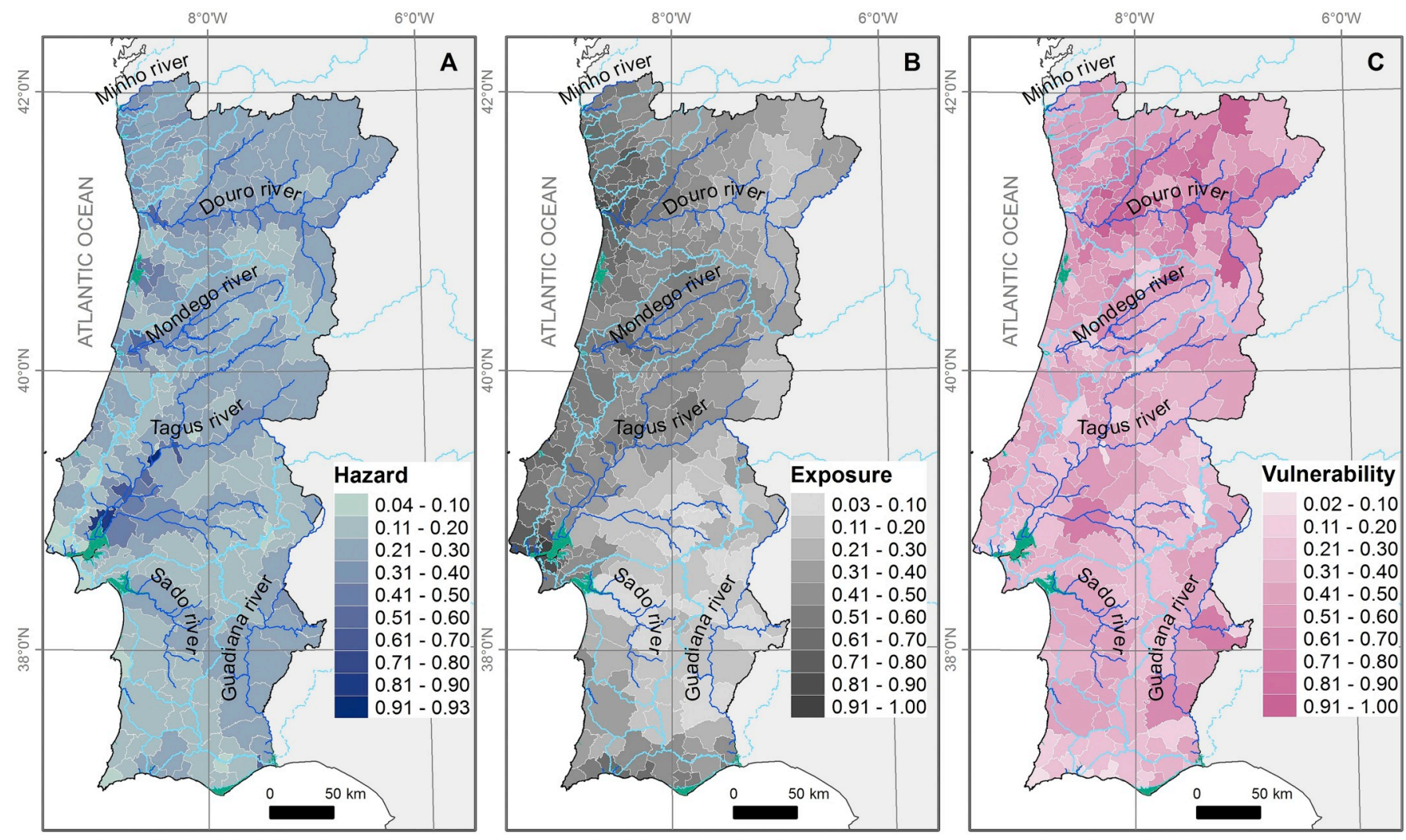

$\sim$ Main rivers $\sim 3$ Basins of major rivers $\sim$ Surface water body

Fig. 6. The components of flood risk: A - hazard (H1), B - exposure (E3), C - vulnerability (V). 


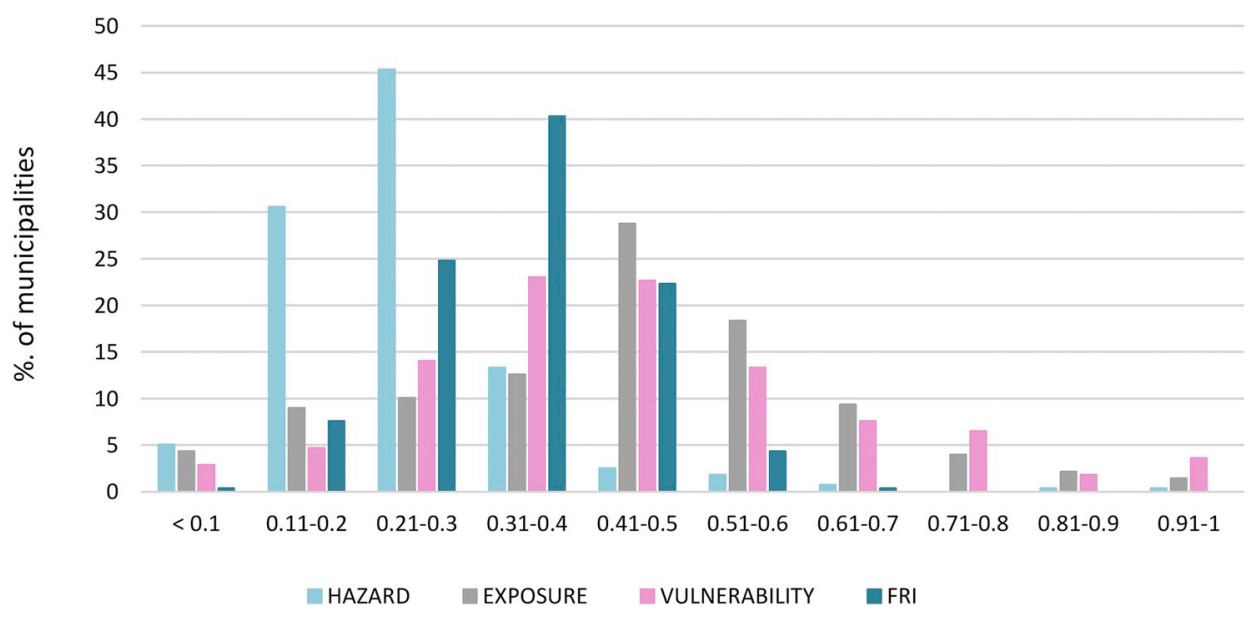

Fig. 7. Frequency of municipalities according to Hazard, Exposure, Vulnerability, and FRI in deciles.

caused 95 fatalities, 323 injuries, and 680 displaced persons. In the Portuguese context, these figures are extremely high and illustrate how localized hazard hotspots can cause significant impacts, justifying the high scores of FRI.

When combining hazard and vulnerability dimensions with exposure, the coastal municipalities where human presence - reflected in high population and road densities as well as in high rates of surface sealing - coincides with lowlands and floodplains are evidenced, presenting high FRI (Fig. 8-A). Cluster analysis performed using hazard, exposure, and vulnerability outputs allowed the identification of seven clusters of municipalities with different characteristics (Fig. 8-B).

Cluster 1 sums 83 municipalities and is partly similar to cluster 4 (35 municipalities) in terms of the relationships between $\mathrm{H}, \mathrm{E}$, and V (Fig. 9), although the average FRI is higher in cluster 1 (0.34 against 0.26). Exposure and vulnerability, by this order, are the main drivers of risk in these 118 municipalities. Historical flood records include the Coimbra municipality in cluster 4 (cf. Fig. 8-B) as an unexpected individual with an FRI 0.322. Coimbra would be expected to be in a cluster with higher values for $\mathrm{H}$ and E. Eventually, in Coimbra, the extensive record of flood losses is discordant with the hazard score (0.335), although it is concordant with the high human occupancy near the main river (Mondego) and the other smaller watercourses that cross the built-up areas (E

0.632). The low LRI in Coimbra is also explained by the low vulnerability (0.157).

Cluster 2 groups 24 municipalities that generally lie within the NW coastal sector of mainland Portugal. These feature the same typology in

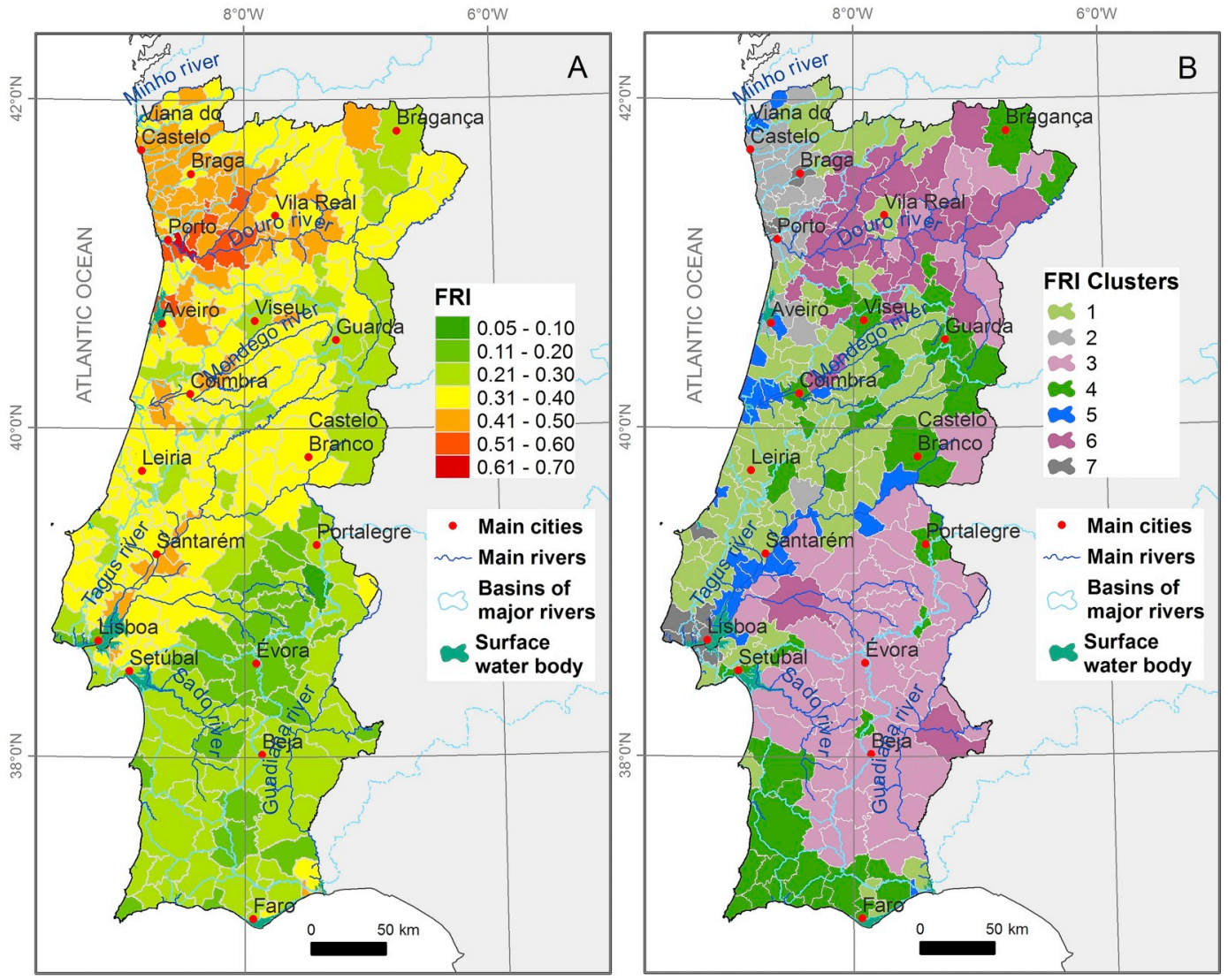

Fig. 8. FRI (A) and FRI clusters of municipalities (B). 


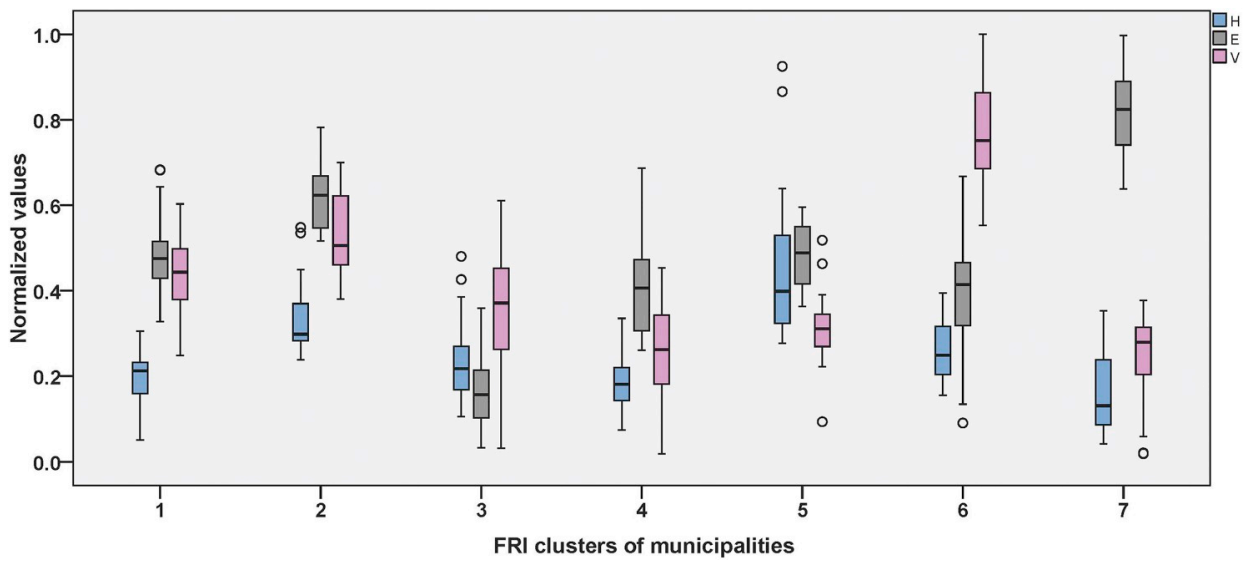

Fig. 9. FRI clusters of municipalities and the respective normalized values for Hazard, Exposure, and Vulnerability.

terms of their $\mathrm{H}, \mathrm{E}$ and $\mathrm{V}$ combination, although with higher average values than clusters 1 and 4 .

Cluster 7 (18 municipalities) stands out by having exceptionally high values of exposure and a low average for $\mathrm{H}(0.16)$ and vulnerability (0.24) (Fig. 8). This cluster includes the main cities of Lisbon, Porto, and Braga, and some of the surrounding metropolitan municipalities.

Cluster 3 and cluster 6, which includes 51 and 47 municipalities, respectively, represent the municipalities where vulnerability is the main driver of risk from flooding. Some of these are crossed by large rivers, such as the Douro, but this does not reflect in high $\mathrm{H}$ given the narrow morphology of the valley and the consequent confinement of the flood-prone areas.

Finally, 20 municipalities are grouped into cluster 5, representing the municipalities where hazard is the most relevant risk driver, which present an average FRI value of 0.46 with two exceptional outliers (Figs. 8-B and 9): Golegã and V.F. Xira (located on the lower section of the Tagus valley), both of which include vast portions of the Tagus river floodplain. Exposure is also a main driver of risk in cluster 5. Apart from the Tagus valley, municipalities in this cluster are found in the floodplains of the Mondego, Vouga, and Minho basins (Fig. 8-B).

\section{Discussion}

\subsection{Design, calculation, and the limitations of the flood risk index}

Global or regional level flood risk assessments are useless at the level of channels or floodplains, and, as well as, in opposition, local and detailed analysis require an upscale generalization in order to be readable and capable of supporting decision-makers and policy entrepreneurs at high levels in strategic FRM.

The flood risk index at the municipality level results from an ascertained process that is based on previously tested assumptions to compute hazard, exposure and vulnerability. The selection of the respective input datasets and the tested combinations of weights was based on the statistical results, expert knowledge of their geographical distribution in the study area, and the existing literature. Therefore, the weighting considered in this study may not be directly applicable to other study areas.

However, the evaluation of the risk components presents some limitations. The assessment of flood hazard using the data represented in the WCE index implies a certain degree of simplification, since the hazard model is used to characterize both flash floods and slow onset floods, with distinct and different rainfall triggers. In many municipalities, the hazard from flooding only affects a small portion of the total municipal territory, meaning that the representation of flood hazard as an average value of a larger area leads to two distinct effects: the attenuation of local hotspots of flood hazard; and, in municipalities crossed by major rivers, the hazard index result may be increased because high values of susceptibility found within a small area can affect the entire municipality. Concerning the social and institutional factors that influence risk - flood preparation and prevention measures - the FRI does not assess directly the coping capacity, the institutional "building" of risk governance, or the self-protection measures carried out by residents. Some of these aspects would be impracticable to assess on a national level.

Regarding the exposure component of risk, a wider list of variables could be used, such as those applied in the HANZE database (Paprotny et al., 2018a), which also uses administrative terrain units for analysis. Ultimately, the three variables used to describe exposure in the FRI are the most commonly used as they express both the population and the exposed elements (through the consideration of artificialized areas and the road network) that are also considered in the HANZE database. Another aspect to discuss regarding the assessment of exposure is the weight assignment, which values the road network more than the other factors. This is rooted in the fact that the pattern of the geographical distribution of flood losses shows that they occur not only in areas with a high population density or a high percentage of impervious areas. This is particularly evident if the minor losses (agricultural losses, roadblocks) and, surprisingly, the distribution of casualties are considered. Previous research using data concerning human loss from the DISASTER database (Pereira et al., 2016) and minor losses in specific basins (Santos and Reis, 2018; Tavares et al., 2013) clearly demonstrates the relevance of contexts where the population is less dense, such as the transportation network in rural and suburban areas.

Vulnerability is the most dynamic of the FRI components over time. The majority of the explicative variables used in the PCA date from the Population Census of 2011, although it also includes more recent data (particularly from 2017). The analysis of V would be more accurate if a nationwide assessment of the physical vulnerability of all buildings, at the municipal level, was available. Despite this limitation, the assessment of vulnerability considers several territorial dimensions - other than those that are exclusively social (age, gender, or employment, for example) -, that are represented in the SV components for criticality and support capability (Tavares et al., 2018). The use of a social dimension in the assessment of vulnerability was justified by the extensive spatial coverage of the hazard; while slow-onset floods are restricted to well-mapped areas, flash floods can potentially occur in any watershed with no exemptions. Floods cause both direct and indirect impacts. For example, roads in the Mondego and Tagus basins often become cut-off over a period of one or more weeks by flooding, or a bridge may be destroyed by a flash flood in a small watershed. Such events can affect households that are not directly affected by the water levels, leading to the argument that social, economic, and health conditions are as important as physical vulnerability in anticipating and managing the 
disruption or damage caused either directly or indirectly by flooding.

Similar to the perspective of the HANZE database (Paprotny et al., 2018a) the indexes presented attempt to standardize the assessment and comparison of flood triggers (hazard) and flood impact-conditioning factors (exposure and vulnerability) over large administrative unit areas. It is recognized that the triggering thresholds and conditioning factors for slow-onset and flash floods differ, and are therefore associated with distinct impacts. An attempt to consider this fact was made by choosing a method for assessing $\mathrm{H}$ in which large watersheds were distinguished from small watersheds in the SFS, while the MFPA identifies large and small flood-prone areas, and the WCE uses variables that are related to both long and short rainfall events. Ultimately, like most of the global, national and regional indexes do, we need to acknowledge that all these intermediate inputs are mixed and concealed in a single FRI score. Some of the limitations assumed in global or continental databases such as the HANZE - regarding the homogeneity, resolution and data structure of baseline maps and historical statistics - are not observed in the construction of the FRI. By using common data sources from both nationwide and European-wide databases, any bias introduced from the collection and integration of the data at a municipal level is avoided.

The strength of these types of indexes relies on the fact that each component in the FRI is independent and therefore does not theoretically present collinearity with the others. For example, this implies that the vulnerability index is independent from the hazard assessment (Fekete, 2009: p. 400), regardless of any random collinearity that may exist among the risk components. One example of this in this study is the strong correlation between flood hazard and vulnerability in the Douro valley, although both components are completely independent from each other.

\subsection{Replicability and methodological advantages of adopting a municipal level of representation}

The methodology applied in the assessment of the hazard, exposure, and vulnerability elements included in the FRI presents a high potential for replicability in other geographical contexts. The data that is necessary to assess flood susceptibility is generally available even in a datascarce context. Eventually, the meteorological precipitation-related data that is necessary to calculate the EPSI, which is used in the evaluation of the climatic forcers, may not be collected or available in some regions. The same applies to the evaluation of vulnerability, as some data regarding the social equipment and infrastructure may not exist at the municipal level, or its equivalent, in other areas of study, particularly with respect to the support capability component.

Representing risk components at the municipal level allows the balancing of two relevant aspects of disaster risk governance; the optimal scale at which risk assessments are performed and the decisionmaking level at which disaster risk-related decisions are made. In the context of mainland Portugal, which covers approximately $89000 \mathrm{~km}^{2}$, but has only 23 NUT3 units, 278 municipalities, and 2882 civil parishes, municipality-level research was chosen. Opting for representation at a civil parish level would allow for better territorial accuracy in classifying hazard, exposure, and vulnerability, but it would increase the difficulty in strategic decision-making and planning that is carried out by the national, district, and NUT3/regional administrative bodies. This concept requires additional scientific-based evidence, which should be carried out in future research.

\subsection{Applications in flood risk management}

\subsubsection{Exploring the drivers of flood risk considered in the FRI}

The flood risk index provides useful information for the definition of FRM measures, particularly within a medium-to long-term time-frame, as well as to predict the economic viability of non-structural measures as, for instance, insurance schemes. By identifying priority areas for the allocation of material and financial resources, the applicability of the FRI information is intended to be used on a national and district level scale of decision-making. The municipal FRI is meant to support the adoption of FRM strategies at these levels of action and not at the municipal level, although it does provide municipal authorities with the ability to frame their municipality within both a district and national context. The FRI is not intended to be a tool used for risk-zoning at the floodplain or the valley scale of intervention, contrary to the Flood Directive mapping. On a more detailed level, Koks et al. (2015) combined data concerning flood hazards, exposure, and social vulnerability to create an index which could provide useful information for the definition of FRM measures, such as the adoption of specific building codes and insurance schemes. This type of approach can be applied to selected areas based on the results of the FRI.

While the FRI scores provide a composite and comparable indication of risk, the FRI clusters provide an interpretation of which risk components (hazard, exposure, and vulnerability) have the greatest influence on the FRI score. For example, the FRI scores of the municipalities that belong to clusters 3 and 6 suffer from vulnerability more than hazard or exposure. This aspect has implications in the adoption of the FRM strategies that may be more suited to each cluster. For example, in municipalities of clusters 1 and $2, \mathrm{H}$ is notoriously lower that $\mathrm{E}$ and $\mathrm{V}$, and the overlay between box-plots is almost absent. Therefore, planning strategies that involve a reduction to the hazard component should not be a priority in these municipalities (Fig. 9).

Flood risk governance must be tackled via diversity in the dimensions and levels of governance, with urban planning, social assistance, environment, agriculture, forestry, mobility, energy, among others, and civil protection playing important roles. These factors participate differently in the disaster cycle of FRM. While some are mainly dedicated to the contingency of daily activities and the long-term reduction of disaster risk, others must plan and operate while floods are imminent, are occurring, or have just occurred. At the strategic level of FRM, the risk drivers identified by the results of the FRI constitute relevant knowledge concerning the type and number of resources that should be devoted to mitigation, both at the national and the district level, and in which aspects public or private stakeholders should be involved. Municipalities in cluster 6 , for example, are marked by high social vulnerability and low levels of flood hazard, which should inform decision-makers to prioritize their actions on the social factors that cause vulnerability instead of in resources that control or mitigate flood hazard. The Sendai Framework for Action clearly assumes the pivotal role of Governments on DRR at both the national and local level (UNISDR, 2015b).

At the municipal level of FRM decision-making, the research presented in this paper is useful as a tool to position each municipality in a national context. It also allows a comparison of how similar municipalities manage flood risks. Finally, it allows a simulation of how changes in any of the components ( $\mathrm{H}, \mathrm{E}$ and $\mathrm{V}$ ) influence the value of FRI, and how intervention in the specific causes of flood risk can be attained. The municipalities of Santo Tirso ( $40 \mathrm{~km} \mathrm{NE}$ of Porto) and V.F. Xira (30 km NE of Lisbon) present a FRI score of 0.48 (see the supplementary material for a more detailed location). However, the main drivers of risk in Santo Tirso are exposure and vulnerability (with a score of approximately 0.60 for both drivers) and a value for the hazard component of only 0.29 , while V.F. Xira presents an $\mathrm{H}$ of 0.87 (one of the highest in the country), an $\mathrm{E}$ of 0.49 , and a low V of only 0.26 . Understanding the drivers of flood risk can inform policy makers and planners at the national and NUTs level about the types of measures that should be prioritized for reduction, adaptation, and mitigation in inter-sectorial risk management. This purpose is similar to the type of analysis that is produced by the INFORM at the global level (INFORM, 2018) but on a different scale, prioritizing regions for increased disaster prevention, preparedness, and response. By also addressing exposure and vulnerability, these indexes identify the potential drivers of impacts and enable local analysis that can provide a greater insight on the causes and 
potential solutions, in order to reduce disaster risk.

Historically, there have been municipalities - such as the highly urbanized municipalities west of Lisbon, for example - that have a low FRI but present a moderate record of flood losses, in the national context. In such cases, only the inclusion of the database concerning losses can help to identify the municipalities that require particular attention in terms of flood risk management. This disparity between the FRI score and the records of loss in some municipalities also highlights the relevance of the discussion on the quantitative analysis of flood risk that only considers the hazard, exposure, and vulnerability, without accounting for the historical impacts. Thus, further advancements in the research are required that make use of spatially consistent and criteriastandardized national disaster databases (Zêzere et al., 2014), using an approach similar to that adopted by the HANZE database, for example, by crossing population, exposure, and the loss from floods.

\subsubsection{The relationship between the FRI and the European Floods Directive}

This research does not intend to overwrite the purposes or the type of risk assessment made in the scope of the European Floods Directive (FD), which focused on only 22 critical areas, most of which are short segments of major river systems. Instead, the FRI and its components are aimed at providing a comparative perspective of an entire country, to prioritize and inform the next risk assessment phases. The FRI is able to identify current risk areas and simulate expected changes on risk drivers $(\mathrm{H}, \mathrm{E}$, and $\mathrm{V}$ ), therefore contributing to the identification of potential areas that should be considered in the scope of the FD.

The selection criteria of the 22 critical areas identified in the 1 st cycle of the FD was based on historical records of floods and the loss associated with these floods and not on flood susceptibility or flood hazard data. Upon the initial selection, flood-prone areas were identified using hydrologic and hydraulic modelling. A common characteristic of all the 22 areas is to have registered in a given period (which was not indicated in the Flood Risk Management Plans), a minimum of 1 fatality, and 15 affected persons (evacuated or displaced). Considering the flood-prone areas of the longest return period (1000 years), the areas covered by the 22 critical areas varied between $0.05 \mathrm{~km}^{2}$ in a small basin in a municipality located in the south, to the $502.55 \mathrm{~km}^{2}$ of the Tagus river floodplain (covering 15 municipalities), with a median of $5.7 \mathrm{~km}^{2}$. Despite this, the overlay of the FD flood-prone areas with the municipal SFS, MFPA, and SUSCF (Figs. S1, S2 and S3) clearly shows a spatial correlation (c.f. also Fig. S4), which could not occur.

The risk assessment made by the FRI and the FD differs significantly, simply via the diversity in the purpose and conceptual approaches of both methods, although complementary in our perspective. The difference relies on the fact that the FD assessment is used to classify the risk within a floodplain, which implies that very low and very high-risk classes can coexist within a few hundred meters or less. In opposition, the FRI is aimed at the strategic level; it differentiates and ranks municipalities by combining the inputs from each risk driver.

55 of the 278 Portuguese municipalities have some territory mapped by the FD implementation phase. Considering not only susceptibility, but also exposure and vulnerability, other areas can also be included in future cycles, in which the latter two drivers may be equal to or greater than the physical constraints of flooding. In Portugal, an unpublished analysis from the first author of this paper, regarding the implementation actions defined in the 1st generation of one of the FRMPs (the Hydrographical Region 4) clearly evidences that most of the funding $(98 \%)$ is devoted to structural interventions rather than to nonstructural measures. In that same FRMP, 30 of the 54 proposed measures for the Vouga, Mondego and Lis basins (Central Portugal) are soft or non-structural measures (mostly plans, early warning systems, and civil protection exercises). The measures of a structural nature (defense works, river channeling, etc.), although smaller in number, are several times more expensive. A diversification in FRM strategies should be sought, demonstrating the benefits of soft measures through cost-benefit analysis and similar approaches (e.g. risk prevention, education, risk preparedness, or spatial planning) as well as of the blue and green infrastructure in reducing disaster risk. These approaches take place over longer time scales and their effectiveness is less easily quantifiable in comparison to the traditional structural interventions.

Diversification can be seen in the approaches used for the implementation of the FD across Europe (Hegger et al., 2018), recommending a "focus on prevention, protection, and preparedness" (EC, 2007). The United Kingdom follows a non-structural line of action, although it was already in place even before the FD approval, while Germany is evolving from a dominant flood defenses approach to a non-structural one, privileging prevention and mitigation (Bubeck et al., 2017). Countries such as the Netherlands, which face low probability but high expected loss and short warning times, still rely primarily on structural measures but the implementation of the FD has reinforced the recognition that a certain residual risk will always remain and therefore water authorities are complementing the structural portfolio with other, non-structural measures (Bubeck et al., 2017).

\section{Conclusions}

An index that is used to express the risk from flood was presented in this study, considering the components of hazard, exposure, and vulnerability. A diverse set of base-variables was selected and integrated within a GIS environment for representation on a municipal level. The weighting of the variables inside each component was sequentially tested and validated in order to obtain a score for each of the three components, following the approach of the global INFORM multi-risk index. The results show the existence of areas in which climatic, geomorphologic, and hydrologic factors superimpose areas with high demographic, road and urban development, resulting in high scores for flood risk. These areas are located mainly in the NW sector of the country and in the Mondego and the Tagus river valleys.

Carrying out cluster analysis on the FRI results provides an integrated understanding of the drivers of flood risk in each municipality, identifying which risk components are a priority to be addressed on both a national and a district level of risk management. The results leverage a desirable diversification of FRM strategies, balancing the so-far predominant interventions of a structural nature with strategies that can be used to plan the long-term reduction of hazard, exposure, and vulnerability.

\section{Additional material}

The intermediate and final results of the Flood Risk Index can be consulted interactively at the following address: http://www.ceg.ulisbo a.pt/forland/en/. This tool includes data at the municipal level regarding the reported historical impacts related to flooding, in the period 1865-2015.

\section{Author contribution statement}

List of Authors: Pedro Pinto Santos, Susana Pereira, Jose Luís Zêzere, Alexandre Oliveira Tavares, Eusebio Reis, Ricardo A. C. Garcia, Sergio Cruz Oliveira.

The Flood Risk Index (FRI) input data was provided and discussed by: Hazard data (particularly from PP Santos, S Pereira, JL Zêzere, E Reis, RAC Garcia and SC Oliveira), Exposure data (All the authors), Vulnerability data (particularly from AO Tavares and PP Santos).

All the Authors (PP Santos, S Pereira, JL Zêzere, AO Tavares, E Reis, RAC Garcia, SC Oliveira) contributed to the design of the FRI model.

PP Santos and S Pereira wrote the initial version of the paper based on all the Authors contributions. All the Authors reviewed the paper before submission to the journal. 


\section{Acknowledgements}

This work was financed by national funds through the FCT-Portuguese Foundation for Science and Technology, I.P., under the framework of the project FORLAND - Hydro-geomorphologic risk in Portugal: driving forces and application for land use planning (PTDC/ATPGEO/ 1660/2014) and by the Research Unit UIDB/GEO/00295/2019. Pedro Pinto Santos is funded by FCT through the project with the reference CEEIND/00268/2017.

\section{Appendix A. Supplementary data}

Supplementary data to this article can be found online at https://doi. org/10.1016/j.jenvman.2020.110127.

\section{References}

Alfieri, L., Burek, P., Feyen, L., Forzieri, G., 2015. Global warming increases the frequency of river floods in Europe. Hydrol. Earth Syst. Sci. 19, 2247-2260. https:// doi.org/10.5194/hess-19-2247-2015.

APA, 2018. SNIAmb - Environment Information National System. Portuguese Environmental Agency [WWW Document]. URL. https://sniamb.apambiente.pt/.

EC, 2007. Directive 2007/60/EC of the European Parliament and of the Council of 23 October 2007 on the Assessment and Management of Flood Risks.

Bubeck, P., Kreibich, H., Penning-Rowsell, E.C., Botzen, W.J.W., de Moel, H., Klijn, F., 2017. Explaining differences in flood management approaches in Europe and in the USA - a comparative analysis. J. Flood Risk Manag. 10 (4), 436-445. https://doi. org/10.1111/jfr3.12151.

CLMS, 2012. Imperviousness Degree (CLC 2012). Copernicus Land Monitoring Service [WWW Document]. URL. https://land.copernicus.eu/about. (Accessed 12 October 2017).

Cortesi, N., Gonzalez-Hidalgo, J.C., Trigo, R.M., Ramos, A.M., 2014. Weather types and spatial variability of precipitation in the Iberian Peninsula. Int. J. Climatol. 34, 2661-2677. https://doi.org/10.1002/joc.3866.

De Groeve, T., Vernaccini, L., Polansek, K., 2014. Index for risk management - InfoRM Report EUR 26528 EN. https://doi.org/10.2788/78658.

DGT, 2015. Land Use Chart - 2015. Directorate-General of the Territory [WWW Document]. URL: https://www.dgterritorio.pt.

Dieperink, C., Hegger, D.L.T., Bakker, M.H.N., Kundzewicz, C., Green, C., Driessen, P.P. J., 2016. Recurrent governance challenges in the implementation and alignment of flood risk management strategies: a review. Water Resour. Manag. 30 (13), 4467-4481. https://doi.org/10.1007/s11269-016-1491-7.

Dottori, F., Salamon, P., Bianchi, A., Alfieri, L., Hirpa, F.A., Feyen, L., 2016. Development and evaluation of a framework for global flood hazard mapping. Adv. Water Resour. 94, 87-102. https://doi.org/10.1016/J.ADVWATRES.2016.05.002.

Driessen, P.P., Hegger, D.L., Bakker, M.H., Rijswick, H.F., Kundzewicz, Z.W., 2016. Toward more resilient flood risk governance. Ecol. Soc. 21 (4), 53. https://doi.org/ 10.5751/ES-08921-210453.

Fekete, A., 2009. Validation of a social vulnerability index in context to river-floods in Germany. Nat. Hazards Earth Syst. Sci. 9, 393-403. https://doi.org/10.5194/nhess9-393-2009.

Fernandez, P., Mourato, S., Moreira, M., 2016. Social vulnerability assessment of flood risk using GIS-based multicriteria decision analysis. A case study of Vila Nova de Gaia (Portugal). Geomatics, Nat. Hazards Risk 7, 1367-1389. https://doi.org/ 10.1080/19475705.2015.1052021.

Ferrari, S., Oliveira, S., Pautasso, G., Zêzere, J.L., 2019. Territorial resilience and flood vulnerability. In: Case Studies at Urban Scale in Torino (Italy) and Porto/Vila Nova de Gaia (Portugal). Springer, Cham, pp. 147-174. https://doi.org/10.1007/978-3319-76944-8_10.

Ferreira, A. de B., Medeiros, C.A., Ferreira, D. de B., Ramos, C., Moreira, M.E., Neto, C. da S., 2005. O Ambiente Físico (vol. I). In: Medeiros, C.A. (Ed.), Geografia de Portugal. Círculo de Leitores, Rio de Mouro, p. 496.

Fournier, M., Larrue, C., Alexander, M., Hegger, D., Bakker, M., Pettersson, M., Crabbe, A., Mees, H., Chorynski, A., 2016. Flood risk mitigation in Europe: how far away are we from the aspired forms of adaptive governance? Ecol. Soc. 21, art49. https://doi.org/10.5751/ES-08991-210449.

Geaves, L.H., Penning-Rowsell, E.C., 2016. Flood Risk Management as a public or a private good, and the implications for stakeholder engagement. Environ. Sci. Policy 55, 281-291. https://doi.org/10.1016/J.ENVSCI.2015.06.004.

Green, C., Dieperink, C., Ek, K., Hegger, D., Pettersson, M., Priest, S., Tapsell, S., 2013. Flood Risk Management in Europe: the Flood Problem and Interventions (STARFLOOD).

Hartmann, T., Driessen, P., 2017. The flood risk management plan: towards spatial water governance. J. Flood Risk Manag. 10, 145-154. https://doi.org/10.1111/jfr3.12077.

Hegger, D.L.T., Driessen, P.P.J., Bakker, M.H.N., 2018. Diversification of flood risk management strategies-necessity and importance. In: Raadgever, Tom, Hegger, Dries (Eds.), Flood Risk Management Strategies and Governance. Springer, Cham. https:// doi.org/10.1007/978-3-319-67699-9_2.

Hobeica, L., Santos, P., 2016. Design with floods: from defence against A "Natural" threat to adaptation to a human-natural process. Int. J. Saf. Secur. Eng. 6, 616-626. https://doi.org/10.2495/SAFE-V6-N3-616-626.
INE, 2011. Population Census - 2011. Statistics Portugal [WWW Document]. URL: https://www.ine.pt.

INFORM, 2018. INFORM Global Risk Index. Results 2018. Inter.-Agency standing Committee Reference Group on Risk, Early Warning and Preparedness and the European Commission. https://doi.org/10.2760/754353.

IPCC, IPCC5 WGII, 2014. Climate Change 2013, the Fifth Assessment Report.

Koks, E.E., Jongman, B., Husby, T.G., Botzen, W.J.W., 2015. Combining hazard, exposure and social vulnerability to provide lessons for flood risk management. Environ. Sci. Policy 47, 42-52. https://doi.org/10.1016/j.envsci.2014.10.013.

Mendes, J.M., Tavares, A.O., Freiria, S., Cunha, L., 2010. Social vulnerability to natural and technological hazards: the relevance of scale. In: Bris, B., Soares, C.G., Martorell, M. (Eds.), Reliability, Risk and Safety: Theory and Applications. ESRA and Taylor \& Francis Group, pp. 445-451.

Mendes, J.M., Tavares, A.O., Santos, P.P., 2019. Social vulnerability and local level assessments: a new approach for planning. Int. J. Disaster Resilience in the Built Environment. https://doi.org/10.1108/IJDRBE-10-2019-0069.

Merz, B., Hall, J., Disse, M., Schumann, A., 2010. Fluvial flood risk management in a changing world. Nat. Hazards Earth Syst. Sci. 10, 509-527. https://doi.org/ 10.5194/nhess-10-509-2010.

Nobre, a.D., Cuartas, L.a., Hodnett, M., Renno, C.D., Rodrigues, G., Silveira, a., Waterloo, M., Saleska, S., 2011. Height above the Nearest Drainage - a hydrologically relevant new terrain model. J. Hydrol. 404, 13-29. https://doi.org/ 10.1016/j.jhydrol.2011.03.051.

Okazawa, Y., Yeh, P.J.-F., Kanae, S., Oki, T., 2011. Development of a global flood risk index based on natural and socio-economic factors. Hydrol. Sci. J. 56, 789-804. https://doi.org/10.1080/02626667.2011.583249.

Oliveira, E.O., Ramos, C., 2002. Inundações na cidade de Lisboa durante o seculo XX e seus factores agravantes. Finisterra XXXVII 33-54.

Paprotny, D., Morales-Napoles, O., Jonkman, S.N., 2018a. HANZE: a pan-European database of exposure to natural hazards and damaging historical floods since 1870 . Earth Syst. Sci. Data 10, 565-581. https://doi.org/10.5194/essd-10-565-2018.

Paprotny, D., Sebastian, A., Morales-Napoles, O., Jonkman, S.N., 2018b. Trends in flood losses in Europe over the past 150 years. Nat. Commun. 9, 1985. https://doi.org/ 10.1038/s41467-018-04253-1.

Pereira, S., Zêzere, J.L., Quaresma, I., Santos, P.P., Santos, M., 2016. Mortality patterns of hydro-geomorphologic disasters. Risk Anal. 36, 1188-1210. https://doi.org/ 10.1111/risa.12516.

Pereira, S., Diakakis, M., Deligiannakis, G., Zêzere, J.L., 2017. Comparing flood mortality in Portugal and Greece (western and eastern mediterranean). Int. J. Disaster Risk Reduct. 22, 147-157. https://doi.org/10.1016/j.ijdrr.2017.03.007.

Pereira, S., Ramos, A.M., Rebelo, L., Trigo, R.M., Zêzere, J.L., 2018. A centennial catalogue of hydro-geomorphological events and their atmospheric forcing. Adv. Water Resour. 122, 98-112. https://doi.org/10.1016/j.advwatres.2018.10.001.

Ramos, C., Reis, E., 2001. As cheias no Sul de Portugal em diferentes tipos de bacias hidrograficas. Finisterra 36, 61-82.

Ramos, C., Reis, E., 2002. Floods in southern Portugal: their physical and human causes, impacts and human response. Mitig. Adapt. Strategies Glob. Change 7, 267-284. https://doi.org/10.1023/A:1024475529524.

Ramos, A.M., Cortesi, N., Trigo, R.M., 2014. Circulation weather types and spatial variability of daily precipitation in the Iberian Peninsula. Front. Earth Sci. 2, 1-17. https://doi.org/10.3389/feart.2014.00025.

Reis, E., 2011. Analise de bacias hidrograficas, susceptibilidade a ocorrências de cheias e sistemas de informaçao geografica: da definiçao do quadro conceptual ate a proposta de um modelo de avaliação. In: VIII Congresso Da Geografia Portuguesa. Associaçao Portuguesa de Geografos, Lisbon, pp. 1-6.

Sa, L., Vicêncio, H., 2011. Risco de inundações - uma metodologia para a sua cartografia. Territorium 15, 227-230.

Salgueiro, T.B., Ferrão, J., Medeiros, C.A., Malheiros, J.M., Marques, T.S., PintoCorreia, T., Domingues, A., Matos, F.L., Pacheco, E., Vale, M., 2005. Sociedade, Paisagens e Cidades (Vol. II). In: Medeiros, C.A. (Ed.), Geografia de Portugal -. Círculo de Leitores, Rio de Mouro, p. 419.

Sampson, C.C., Smith, A.M., Bates, P.D., Neal, J.C., Alfieri, L., Freer, J.E., 2015. A highresolution global flood hazard model. Water Resour. Res. 51, 7358-7381. https:// doi.org/10.1002/2015WR016954.

Santos, P.P., Reis, E., 2018. Assessment of stream flood susceptibility: a cross-analysis between model results and flood losses. J. Flood Risk Manag. 11 https://doi.org/ 10.1111/jfr3.12290.

Santos, P.P., Tavares, A.O., 2015. Basin flood risk management: a territorial data-driven approach to support decision-making. Water (Switzerland) 7, 480-502. https://doi. org/10.3390/w7020480.

Santos, P.P., Tavares, A.O., Zêzere, J.L., 2014. Risk analysis for local management from hydro-geomorphologic disaster databases. Environ. Sci. Policy 40, 85-100. https:// doi.org/10.1016/j.envsci.2013.12.007.

Santos, M., Fragoso, M., Santos, J.A., 2017. Regionalization and susceptibility assessment to daily precipitation extremes in mainland Portugal. Appl. Geogr. 86, 128-138. https://doi.org/10.1016/J.APGEOG.2017.06.020.

Santos, P.P., Reis, E., Pereira, S., Santos, M., 2019. A flood susceptibility model at the national scale based on multicriteria analysis. Sci. Total Environ. 667, 325-337. https://doi.org/10.1016/j.scitotenv.2019.02.328.

Sayers, P., Yuanyuan, L., Galloway, G., Penning-Rowsell, E., Fuxin, S., Kang, W., Yiwei, C., Quesne, T.L., YLi, G., Penning-Rowsell, E., Shen, F., 2013. Flood Risk Management: A Strategic Approach. Water Sewerage Journal 202. https://unesdoc. unesco.org/ark:/48223/pf0000220870.

Schanze, J., 2012. Dealing with future change in flood risk management. J. Flood Risk Manag. 5, 1-2. https://doi.org/10.1111/j.1753-318X.2011.01129.x. 
Schanze, J., Hutter, G., Penning-Rowsell, E.C., Nachtnebel, H.-P., Meyer, V., Werritty, A., Harries, T., Holzmann, H., Jessel, B., Koniger, P., Kuhlicke, C., Neuhold, C., Olfert, A., Parker, D., Schildt, A., 2008. Systematisation, evaluation and context conditions of structural and non-structural measures for flood risk reduction. In: FLOOD-ERA Joint Report.

Schumann, A.H., 2011. Flood Risk Assessment and Management, Flood Risk Assessment and Management - How to Specify Hydrological Loads, Their Consequences and Uncertainties. Ruhr-University Bochum, Bochum. https://doi.org/10.1007/978-90481-9917-4.

Scussolini, P., Aerts, J.C.J.H., Jongman, B., Bouwer, L.M., Winsemius, H.C., De Moel, H., Ward, P.J., 2016. FLOPROS: an evolving global database of flood protection standards. Nat. Hazards Earth Syst. Sci. 16, 1049-1061. https://doi.org/10.5194/ nhess-16-1049-2016.

Sudhaus, D., Seidel, J., Bürger, K., Dostal, P., Imbery, F., Mayer, H., Glaser, R., Konold, W., 2008. Discharges of past flood events based on historical river profiles. Hydrol. Earth Syst. Sci. Discuss. 5, 323-344. https://doi.org/10.5194/hessd-5-3232008.

Tavares, A.O., Santos, P.P. dos, 2013. Re-scaling risk governance using local appraisal and community involvement. J. Risk Res. 17, 923-949. https://doi.org/10.1080/ 13669877.2013.822915.

Tavares, A.O., Barros, J.L., Santos, P.P. dos, Zêzere, J.L., 2013. Desastres naturais de origem hidrogeomorfologica no Baixo Mondego no período 1961-2010. Territorium 20, 65-76.

Tavares, A.O., Barros, J.L., Mendes, J.M., Santos, P.P., Pereira, S., 2018. Decennial comparison of changes in social vulnerability: a municipal analysis in support of risk management. Int. J. Disaster Risk Reduct. 31, 679-690. https://doi.org/10.1016/J. IJDRR.2018.07.009.

Trigo, R.M., DaCamara, C.C., 2000. Circulation weather types and their influence on the precipitation regime in Portugal. Int. J. Climatol. 20, 1559-1581. https://doi.org/ 10.1002/1097-0088.

Trigo, R.M., Ramos, C., Pereira, S.S., Ramos, A.M., Zêzere, J.L., Liberato, M.L.R., 2016. The deadliest storm of the 20th century striking Portugal: flood impacts and atmospheric circulation. J. Hydrol. 541, 597-610. https://doi.org/10.1016/J. JHYDROL.2015.10.036. n.d. TU-Delft. 4TU - collection: HANZE: historical analysis of natural hazards in Europe [WWW Document]. URL. https://data.4tu.nl/repository/collection:HANZE. (Accessed 26 March 2019).

Turkington, T., Breinl, K., Ettema, J., Alkema, D., Jetten, V., 2016. A new flood type classification method for use in climate change impact studies. Weather Clim. Extrem. 14, 1-16. https://doi.org/10.1016/J.WACE.2016.10.001.

UNISDR, 2015a. Making development sustainable: the future of disaster risk management. In: Global Assessment Report on Disaster Risk Reduction. United Nations Office fo Disaster Risk Reduction, Geneva.

UNISDR, 2015b. Sendai Framework for Disaster Risk Reduction 2015 - 2030. In: Third World Conference on Disaster Risk Reduction, Sendai, Japan, 14-18 March 2015. htt ps://doi.org/A/CONF.224/CRP.1.

Ventura, J.E., 1987. As gotas de ar frio e o regime da precipitação em Portugal. Finisterra XXII, 39-69. https://doi.org/10.18055/Finis2012.

Wallemacq, P., Below, R., McLean, D., 2017. Economic Losses, Poverty and Disasters 1998-2017.

Ward, J., 1963. Hierarchical grouping to optimize an objective function. J. Am. Stat. Assoc. 58, 236-244. https://doi.org/10.1080/01621459.1963.10500845.

Ward, P.J., Jongman, B., Weiland, F.S., Bouwman, A., van Beek, R., Bierkens, M.F.P., Ligtvoet, W., Winsemius, H.C., 2013. Assessing flood risk at the global scale: model setup, results, and sensitivity. Environ. Res. Lett. 8, 044019 https://doi.org/ 10.1088/1748-9326/8/4/044019.

Ward, P.J., Jongman, B., Salamon, P., Simpson, A., Bates, P., De Groeve, T., Muis, S., De Perez, E.C., Rudari, R., Trigg, M.A., Winsemius, H.C., 2015. Usefulness and limitations of global flood risk models. Nat. Clim. Chang. 5, 712-715. https://doi. org $/ 10.1038 /$ nclimate2742.

Welle, T., Birkmann, J., 2015. The world risk index - an approach to assess risk and vulnerability on a global scale. J. Extrem. Events 2, 1-34. https://doi.org/10.1142/ S2345737615500025.

Zêzere, Jose Luís, Pereira, S., Tavares, A.O., Bateira, C., Trigo, R.M., Quaresma, I. Santos, P.P., Santos, M., Verde, J., 2014. Disaster: a GIS database on hydrogeomorphologic disasters in Portugal. Nat. Hazards 72, 503-532. https://doi.org/ 10.1007/s11069-013-1018-y. 